\title{
Las paradojas en la protección al consumidor financiero, en especial en casos de fraude electrónico**
}

DOI: dx.doi.org/10.15425/2017.351

\section{Resumen}

En este artículo se revisan varias situaciones establecidas o permitidas por la ley o la jurisprudencia que en opinión del autor tergiversan el alcance de la protección al consumidor financiero en Colombia, en especial en temas relacionados con fraude electrónico a través de los portales virtuales de los bancos. Para ello, el artículo analiza quién es el consumidor financiero, cuáles son sus obligaciones y las de los bancos que les prestan servicios a través de portales virtuales, y dos sentencias hito en la responsabilidad de estos últimos.

\section{Palabras clave}

Consumidor financiero, portal virtual, fraude electrónico, perfil de las costumbres transaccionales, bancos, mecanismos de seguridad.

* Abogado de la Universidad del Rosario, especializado en Derecho Comercial de la Universidad Javeriana y en Legislación Financiera de la Universidad de los Andes y con un máster universitario en Derecho de los Negocios en la Universidad Francisco de Vitoria y el Colegio de Abogados de Madrid. Profesor en las universidades de Los Andes, Rosario y La Sabana, y en el MBA organizado por la Cámara Colombiana del Acero (Camacero) con la Escuela de Organización Industrial de los ministerios de Educación y de Industria de España, en materias afines al derecho comercial y financiero. Es miembro de Tobar \& Romero Abogados. Dedica este artículo a Emma y Federico, formar hijos en un mundo de solo derechos, y a su tía Carmenza Martínez Aguilera. Cosas del covid. Correo electrónico: cesarrodriguez@trtabogados.com.

** El autor agradece en especial los comentarios recibidos de los ingenieros de sistemas Carlos Eduardo Rodríguez Martínez y Luis Jorge Bonilla Ángel durante las discusiones iniciales de este artículo. 


\title{
Paradoxes in the protection of the Financial Consumer, especially in cases of electronic fraud
}

\begin{abstract}
In this paper, the author reviews several situations established or allowed by law or jurisprudence that, in his opinion, distort the scope of financial consumer protection in Colombia, especially on issues related to electronic fraud through the web portals of the banks. To do this, the article analyzes who is the financial consumer, what are their obligations and those of the banks that provide services through web portals and two landmark sentences in the responsibility of the latter.
\end{abstract}

\section{Keywords}

Financial consumer, web portal, electronic fraud, profile of transactional customs, banks, security mechanisms. 


\section{Introducción}

En este artículo se revisan varias situaciones establecidas o permitidas por la ley o la jurisprudencia que en opinión del autor tergiversan el alcance de la protección al consumidor financiero en Colombia, en especial en temas relacionados con fraude electrónico a través de los portales virtuales de los bancos.

En una primera parte, el artículo analiza los orígenes de la noción de consumidor financiero, a quiénes enmarca, y qué categorías se podrían establecer dentro de esa categoría. Posteriormente, el artículo estudia la existencia o no de obligaciones a cargo de los consumidores financieros y si se pudiera establecer un estándar para el comportamiento de los consumidores cuando son personas jurídicas comerciantes.

En una segunda parte, el artículo estudia los aspectos prácticos de la protección al consumidor financiero teniendo en cuenta los criterios establecidos jurisprudencialmente para que un banco pueda exonerarse en una acción de protección de esta índole. Para ello aborda las obligaciones más representativas de las partes en los contratos para el uso de los portales virtuales en aras de manejar a través de ellos sus productos financieros y su prueba, dando especial atención a las derivadas del perfil de las costumbres transaccionales del consumidor financiero, término que de por sí no tiene una definición legal y en cambio fue objeto de definiciones incongruentes por el Tribunal Superior de Bogotá. Esta parte cierra con las que parecen ser nuevas obligaciones a cargo de las entidades bancarias creadas por la Corte Suprema de Justicia en una sentencia hito en la materia.

Por último, el escrito, aporta unas conclusiones.

Sin perjuicio del análisis realizado, el escrito está estructurado de manera que sea el mismo lector, por medio de preguntas hechas a lo largo de él, quien se responda las distintas paradojas que se advierten.

El contenido de este texto es el siguiente:

- Los aspectos teóricos de la protección al consumidor financiero: quién es él y cuáles son sus obligaciones.

- Los aspectos prácticos de la protección, punto en donde estudiaremos dos jurisprudencias hito.

- Algunas conclusiones. 
PRIMERA PARTE

\section{Los aspectos teóricos de la protección al consumidor financiero: quién es él y cuáles son sus obligaciones}

\section{¿Quién es el consumidor financiero?}

1. La Ley 1328 de $2009^{[1]}$, enfocada en la protección al consumidor financiero, estableció en su artículo 2.D un criterio subjetivo por el que es consumidor financiero "todo cliente, usuario o cliente potencial de las entidades vigiladas" por la Superintendencia Financiera de Colombia (SFC).

A su vez, definió como "cliente" a la "persona natural o jurídica con quien las entidades vigiladas ${ }^{2}$ establecen relaciones de origen legal o contractual, para el suministro de productos o servicios, en desarrollo de su objeto social", tanto en el mercado financiero como en el asegurador o en el de valores.

Para efectos de este trabajo, son entonces ejemplos del variado universo de quienes son "consumidores financieros" bajo la Ley 1328:

"Carmenza Martínez", una señora jubilada de la extinta "Telecom", que tiene una cuenta de ahorros para recibir mensualmente su pensión.

"Vigicol SAS", una compañía con ventas anuales de 10.000 millones de pesos y con 300 empleados, cuyo objeto social está enfocado en servicios de vigilancia, que tiene varias cuentas bancarias y que usa el portal virtual ${ }^{3}$ del banco para el manejo de ellas, por ejemplo para hacer pagos masivos de nómina o de proveedores y para recibir sus ingresos.

"Medicare SAS", una multinacional con más de mil empleados, y con un equipo legal interno acompañado por asesores externos, dedicada a importar

$1 \quad$ Ley $1328 / 2009$.

2 A lo largo de este artículo, la expresión "entidades vigiladas" hará referencia a las entidades financieras, aseguradoras o del mercado de valores, vigiladas por la Superintendencia Financiera de Colombia, no por otras superintendencias. les" o "portales empresariales" de las entidades vigiladas. Un portal de internet (portal web en inglés) es un sitio virtual que ofrece al usuario, de forma fácil e integrada, el acceso a una serie de recursos y servicios relacionados con un mismo tema. Incluye: enlaces, buscadores, foros, documentos, aplicaciones, compra electrónica, etc. Un portal en internet está dirigido principalmente a resolver necesidades de información específica de un tema en particular. "Wikipedia. La enciclopedia libre", Portal (internet), acceso el 9 de enero de 2019, https://es.wikipedia.org/wiki/Portal_(Internet). 
equipos médicos o de ingeniería de alto valor. Ella celebra distintos contratos bancarios de variados montos, por ejemplo, cuentas de ahorro, corrientes, leasings, y contratos de derivados ${ }^{4}$ de cobertura ${ }^{5}$ (contratos de "derivados") y también hace uso del portal virtual.

"JF Duncan Ltd.", una entidad financiera del exterior vigilada por una autoridad supervisora extranjera equiparable a la SFC, que se dedica a la custodia de valores en el ámbito internacional y que contrata como custodio local a la misma fiduciaria en aplicación del libro 37 de la parte 2 del Decreto Único n. ${ }^{\circ} 2555$ de $2010^{[6]}$, modificado por los decretos $1243^{[7]}$ y $1498^{[8]}$ de 2013 (en adelante, DU).

Le pedimos al lector que tenga muy presente a estas personas. Las vamos a estar citando recurrentemente.

Acá está la magia.

Para cerrar hasta este punto ¿suena jurídicamente lógico igualar en una misma categoría de consumidor financiero -y darles a todos el mismo nivel de protección en los términos de la Ley 1328- a grupos tan dispares de personas?, Respecto de algunas sí podríamos suponer que tienen una capacidad jurídica, técnica y económica que les permite: (a) entender mejor los derechos y obligaciones de los contratos qué están celebrando (aun suponiendo que los contratos sean de adhesión y, por ende, que no se pueden negociar) o (b) adoptar sus propias medidas para protegerse del fraude electrónico durante la ejecución de esos contratos (supongamos, para el uso de los portales virtuales) o (c) negociar los contratos si estos no son de adhesión.

“Instrumento derivado. Es una operación cuya principal característica consiste en que su valor razonable depende de uno o más subyacentes y su cumplimiento o liquidación se realiza en un momento posterior. Dicha liquidación puede ser en efectivo, en instrumentos financieros o en productos o bienes transables, según se establezca en el contrato o en el correspondiente reglamento del sistema de negociación de valores, del sistema de registro de operaciones sobre valores o del sistema de compensación y liquidación de valores. Un instrumento financiero derivado permite la administración o asunción de uno o más riesgos asociados a los subyacentes y cumple cualquiera de las dos condiciones siguientes: 2.10.1. No requerir una inversión neta inicial; o 2.10.2. Requerir una inversión neta inicial inferior a la que se necesitaría para adquirir instrumentos que provean el mismo pago esperado, como respuesta a cambios en los factores de mercado." Superintendencia Financiera de Colombia, Circular Básica Contable y Financiera, capítulo XVIII.

5 "Instrumento derivado de cobertura. Es aquél que se negocia con el fin de cubrir una posición primaria de eventuales pérdidas ocasionadas por movimientos adversos de los factores de mercado o de crédito que afecten dicho activo, pasivo o contingencia. Con la negociación de este tipo de instrumentos se busca limitar o controlar alguno o varios de los riesgos financieros generados por la partida primaria objeto de cobertura." Superintendencia Financiera de Colombia. Ídem.

6 DUR. 2555/2010.

7 Decreto $1243 / 2013$. 
Posteriormente, la Ley 1480 de $2011^{[9]}$, referente al régimen general de protección al consumidor, indicó que era consumidor o usuario "Toda persona natural o jurídica que, como destinatario final, adquiera, disfrute o utilice un determinado producto, cualquiera que sea su naturaleza para la satisfacción de una necesidad propia, privada, familiar o doméstica y empresarial cuando no esté ligada intrínsecamente a su actividad económica. Se entenderá incluido en el concepto de consumidor el de usuario"10.

Lo destacado es un aporte nuevo en comparación con el anterior régimen de protección general del Decreto 3466 del 2 de diciembre de 1982, para el cual un consumidor era "Toda persona, natural o jurídica, que contrate la adquisición, utilización o disfrute de un bien o la prestación de un servicio determinado, para la satisfacción de una o más necesidades".

\section{A) Entonces, ¿la Ley 1480 modificó el concepto de 'consumidor financiero' de la Ley 1328 ?}

Para abordar este punto partamos de la base de que la definición de la Ley 1328 -basada en los sujetos - se supone es para consumidores financieros y la de la Ley 1480, basada en la finalidad, para todos aquellos consumidores que no fueran financieros o no tuvieren un régimen especial.

$Y$ esa frontera de aplicaciones era incluso clara a partir de lo dispuesto en el artículo $2 .^{\circ}$ de la Ley 1480 , el cual indica que "las normas contenidas en esta ley son aplicables en general a las relaciones de consumo y a la responsabilidad de los productores y proveedores frente al consumidor en todos los sectores de la economía respecto de los cuales no exista regulación especial, evento en el cual aplicará la regulación especial y suplementariamente las normas establecidas en esta ley".

Sin embargo, la Corte Constitucional de Colombia, en la sentencia C-909 de 2012 (MP: Nilson Pinilla), al decidir una demanda contra algunos apartes de los artículos 2. ${ }^{\circ}$ (artículo que de por sí establece la definición de consumidor financiero) y 11 de la Ley 1328, desdibujó a nuestro juicio esos límites al indicar en su calidad de intérprete de la norma:

$9 \quad$ Ley $1480 / 2011$.

10 En este documento, las cursivas en textos citados son agregados nuestros, salvo que se indique lo contrario. 
Toda persona natural o jurídica que, como destinatario final, adquiera, disfrute o utilice un determinado producto, cualquiera que sea su naturaleza para la satisfacción de una necesidad propia, privada, familiar o doméstica y empresarial cuando no esté ligada intrínsecamente a su actividad económica. Se entenderá incluido en el concepto de consumidor el de usuario.

En otras palabras, las características particulares y personales de quien busca un bien o servicio de carácter financiero, no son óbice para ser considerado consumidor financiero [115], siempre que lo adquirido busque la satisfacción de una necesidad propia, privada, familiar y empresarial, no ligada intrínsecamente a su actividad económica, sin que por ello deban considerarse o añadirse otros factores. Numeral 8.2.3) [énfasis nuestro].

No es un párrafo fácil de leer. Pero después de hacerlo varias veces parece concluirse que Carmenza Martínez, Vigicol, Medicare y JP Duncan son considerados consumidores financieros, sin importar sus características particulares arriba indicadas, "siempre que lo adquirido busque la satisfacción de una necesidad [...] no ligada intrínsecamente a su actividad económica".

Si bien alguien podría decir que ese aparte de la sentencia es obiter dicta y no ratio decidendi, de manera que no obliga a los operadores jurídicos por estar en las consideraciones y no en la parte resolutiva, consideramos que ello no es tan simple, pues el criterio de ubicación (lo que está en la parte resolutiva es ratio decidendi y lo demás es obiter dicta) ha sido superado desde tiempo atrás por la Corte Constitucional, por ejemplo, en las sentencias C-131 de 1999, Alejandro Martínez, y SU-047 de 1999, Carlos Gaviria y Alejandro Martínez, citadas por Diego López Medina al analizar el asunto ${ }^{11}$ :

¿Qué parte de las sentencias de constitucionalidad tiene la fuerza de la cosa juzgada? La respuesta es doble: poseen tal carácter algunos apartes de las sentencias en forma explícita y otros en forma implícita.

Primero, goza de cosa juzgada explícita la parte resolutiva de las sentencias por expresa disposición del artículo 243 de la Constitución.

Segundo, gozan de cosa juzgada implícita los conceptos de la parte motiva que guarden una unidad de sentido con el dispositivo de la sentencia, de tal forma que no se pueda entender éste sin la alusión a aquellos.

Esta forma de entendimiento de los apartes de una sentencia y cuáles de ellos son cosa juzgada que debe acatarse ha sido utilizada incluso en el análisis de 
constitucionalidad de leyes estatutarias. Por ejemplo, la Corte Constitucional en la sentencia C-037 de 1996, MP: Vladimiro Naranjo, la cual estudió el proyecto de ley de reforma de la administración de justicia n. ${ }^{\circ}$ 58/94 Senado y 264/95 Cámara, indicó:

Sólo será de obligatorio cumplimiento, esto es, únicamente hace tránsito a cosa juzgada constitucional, la parte resolutiva de las sentencias de la Corte Constitucional. En cuanto a la parte motiva, como lo establece la norma, esta constituye criterio auxiliar para la actividad judicial y para la aplicación de las normas de derecho en general; sólo tendrían fuerza vinculante los conceptos consignados en esta parte que guarden una relación estrecha, directa e inescindible con la parte resolutiva; en otras palabras, aquella parte de la argumentación que se considere absolutamente básica, necesaria e indispensable para servir de soporte directo a la parte resolutiva de las sentencias y que incida directamente en ella [énfasis nuestro].

Ahora la pregunta que surge es ¿El numeral 8.2.3 de la sentencia C-909/12 tiene una relación "estrecha, directa e inescindible" con la noción legal de consumidor financiero a pesar de no estar en la parte resolutiva de esa sentencia? Consideramos que sí. Para empezar, la demanda que dio lugar a la sentencia C-909 se dirigió precisamente contra la noción de consumidor financiero, luego el análisis de la Corte de ese numeral guarda esa relación que, como un susurro, nos indica que ella es "estrecha, directa, inescindible con la parte resolutiva [...]".

Ahora: también se podría concluir que ese párrafo del análisis de la sentencia de la Corte Constitucional debe interpretarse teniendo en cuenta el principio in $d u-$ bio pro consumitore, de manera que no importa si el servicio o producto contratado por quien se acerca a la vigilada está intrínsecamente ligado o no a su actividad económica, de manera que seguiría siendo un consumidor financiero. Disentimos de esa interpretación, primero, porque ella está enfocada en la interpretación de contratos $^{12}$, no de sentencias; segundo, porque la Corte Constitucional pudo haberla tenido en cuenta en su análisis y no lo hizo.

Ahora imaginemos qué implicaciones tendría para la protección del consumidor financiero si se aplicaran esos dos párrafos a la hora de definir cuáles personas, de todas las que contraten productos financieros, tienen derecho a ser tratados como consumidores financieros, y cuáles no. El efecto sería gigante: no solo en derechos de información, sino también en definición de jurisdicción; baste ver cómo se interpretaría bajo esta óptica la facultad jurisdiccional de la SFC en temas de 
protección al consumidor financiero dada por el artículo 24.2 del Código General del Proceso (CGP) si se concluyera que no todas las personas que celebran contratos con las entidades vigiladas son consumidores financieros por interpretación de lo anterior.

Nuevamente, el espectro de la contratación de productos o servicios ${ }^{13}$ con entidades vigiladas es tan amplio para cuestionarnos cuándo el servicio o producto financiero que se contrata con aquellas está ligado intrínsecamente con la actividad económica del consumidor financiero.

Para hacerlo más interesante, imaginemos algunos ejemplos de la "vida real".

Una persona natural que abre una cuenta de ahorros para recibir su salario o pensión. ¿Ese negocio jurídico está intrínsecamente ligado con su actividad económica? Obvio que no.

Una compañía cuyo objeto social, establecido en el registro mercantil, indica que puede abrir cuentas bancarias o celebrar cualquier contrato con entidades vigiladas por la SFC. ¿Incluir ello en su objeto social hace que los contratos bancarios queden dentro de su actividad económica? Tampoco consideramos que ello sea una actividad "intrínsecamente ligada".

Una compañía floricultora exportadora, y que celebra continuamente contratos de derivados para cubrir el riesgo cambiario, siempre presente en ese tipo de negocios ${ }^{14}$. Acá el asunto cambia. Pues es de esperar que un comerciante exportador cubra sus riesgos cambiarios, ya que intrínsecamente están ligados a su actividad de exportación.

Una persona jurídica que paga las facturas que adeuda a sus proveedores a los 90 días y para ello diseña y contrata con una entidad vigilada una plataforma tecnológica para que aquellos puedan descontarlas antes si lo consideran. Lo dejamos al lector...

Solo por animar más el debate, se podría proponer que algo está intrínsecamente ligado a una actividad cuando ese algo es hecho por la gran mayoría de las personas que se dedican a esa actividad. Por ejemplo, si hay algunos floricultores que contratan coberturas con derivados y otros, una gran mayoría, que no, al no ser entonces algo que haga la gran mayoría de los floricultores, se podría pensar que las coberturas en derivados no están intrínsecamente ligadas a la actividad del dos en este documento sencillamente como "productos".

"Mal asegurados: No cubrirse frente al dólar está saliendo caro", Revista Dinero, 9 de enero de 2016, https://www.dinero.com/edicion-impresa/pais/articulo/como-son-las-coberturas-para-riesgode-dolar/231432. 
floricultor. Pero de aplicar este criterio, si la gran mayoría de los comerciantes de cualquier sector económico o de cierto tamaño patrimonial utiliza portales virtuales para manejar y disponer de los dineros que tienen depositados, podría implicar que ese servicio está intrínsecamente ligado a su actividad y por ende no serían consumidores financieros para tales efectos quienes lo usaran. Incluso, nos aventuramos a decir que la utilización por los comerciantes de cierto tamaño económico de los portales virtuales que les ofrecen los bancos para hacer cargues y pagos masivos de los salarios de sus empleados es ya una práctica absolutamente reiterada.

En el ámbito internacional, que no es el objeto de este artículo, más enfocado en situaciones nacionales, en una revisión de la regulación en la Unión Europea, España, Argentina y Perú por Alfredo Sánchez Belalcázar, este concluyó que “En resumen, en las tendencias internacionales analizadas, una simple muestra, la noción de consumidor, que se extiende al cliente o usuario bancario siempre se encuentra condicionada a la destinación final del acto que debe ser ajeno a actividades empresariales o profesionales. Puede haber distintas tendencias en cuanto al 'sujeto consumidor', limitándolo en algunos eventos a personas físicas o naturales o extendiéndolo, en otros, a las personas jurídicas, pero en todos los casos atados a la existencia de una relación de consumo"15.

\section{B) ¿Qué ha dicho la SFC al respecto sobre la noción de 'consumidor financiero'?}

En el concepto 2013075203, del 25 de noviembre de 2013 ${ }^{[16]}$, la Dirección de Protección al Consumidor indicó:

$[\ldots]$

(b) A manera de conclusión.

Esta Superintendencia considera que la noción legal de consumidor financiero no toma en cuenta diferencia alguna entre persona natural o jurídica, formación o nivel económico o educativo, o la finalidad perseguida por este. Dicho de otra forma, no resulta procedente identificar la motivación o finalidad del servicio financiero contratado o a contratar, para determinar si alguien es "consumidor financiero" [...] Lo anterior, dada la claridad normativa de la noción de "consumidor financiero" establecida actualmente en la Ley 1328 [...]. 
En síntesis, esta dirección aplicó una interpretación literal de la ley sin analizar el criterio de la Corte Constitucional de la denominada "cosa juzgada implícita" arriba explicado.

Y en auto del 21 de mayo de 2015 (expediente 2015-0206) ${ }^{17}$ la Delegatura para Funciones Jurisdiccionales de la SFC indicó que para analizar si había una relación de consumo en el sector financiero se debía verificar "la interrelación de dos sujetos en condiciones de desigualdad" entre la vigilada y el contratante, lo cual se revisa a través de criterios que "difícilmente pueden estandarizarse", si bien identifica dos de ellos: "(1) la capacidad de negociación de las partes al momento de suscribir un contrato o pactar las condiciones en que se ha de adquirir determinado bien o servicio y (2) el grado de especialidad y conocimiento de las partes sobre la materia o aspectos involucrado en el proceso de producción del bien o servicio que se adquieren".

Creemos que esta segunda posición tiene un mayor fundamento y está más acorde con la diversidad en el "cuasi-infinito" número de personas con singulares características que contratan productos con entidades vigiladas, pues tiene en cuenta no solo el obvio criterio subjetivo de "alguien que contrata con una entidad vigilada" sino también otros elementos que si bien no son del tipo del "ligado intrínsecamente" que fue reconocido por la Corte Constitucional y desconocido por la Delegatura de Protección al Consumidor Financiero, sí parecieran dar cabida a que en ciertos casos una persona contratante pueda no ser un consumidor financiero.

Por tanto, pareciere que, hipotéticamente, una persona podría no ser consumidor financiero, a pesar de haber contratado con una entidad vigilada, (1) si tuvo capacidad para negociar los términos de su contrato o si tuvo capacidad para pactar las condiciones en que adquiere un bien o servicio financiero y (2) si tiene un grado de especialidad y conocimiento sobre el producto o servicio financiero que contrata.

\section{C) Para cerrar: la incógnita del segundo inciso del artículo $1 .^{\circ}$ de la Ley 1328}

Hay un punto adicional que también profundizaría el debate: el artículo $1 .^{\circ}$ de la Ley 1328:

Artículo $1^{\circ}$. Objeto y ámbito de aplicación. El presente régimen tiene por objeto establecer los principios y reglas que rigen la protección de los consumidores 
financieros en las relaciones entre estos y las entidades vigiladas por la Superintendencia Financiera de Colombia, sin perjuicio de otras disposiciones que contemplen medidas e instrumentos especiales de protección.

Para los efectos del presente título, se incluye dentro del concepto de consumidor financiero toda persona que sea consumidor en el sistema financiero, asegurador y del mercado de valores.

Esta norma no fue demandada, y tampoco fue analizada por la Corte Constitucional en la sentencia C-909. Teniendo en cuenta la cronología del Decreto $3466 / 82$, la Ley 1328/09 y la Ley 1480/11, pareciera que ese segundo párrafo hace referencia a la noción de consumidor del Decreto 3466, norma que fue derogada por la Ley 1480.

Así mismo, este segundo numeral sólo se incorporó al proyecto de ley cuando este fue aprobado en plenaria del Senado y la Cámara ${ }^{18}$. Surgen entonces algunas preguntas:

¿La noción a la que hace referencia la expresión consumidor de este inciso haría ahora referencia a la noción de consumidor de la Ley 1480 ?

¿Significa que en el sistema financiero, bursátil y asegurador se entiende que son consumidores los que encuadren en la noción de consumidor financiero de la Ley 1328 los que encuadren en la noción de consumidor de la Ley 1480 y los que encuadren en ambas?

¿O significa que la noción de consumidor financiero debe tener en cuenta ahora el criterio de finalidad de la noción de consumidor de la Ley 1480 ?

¿O simplemente es una aclaración necesaria para reforzar que la noción de consumidor financiero aplica también en los ámbitos asegurador y de mercado de valores, los cuales podrían entenderse que no son estrictamente ámbitos "financieros"?

Pero dejemos esta primera paradoja, sin detenernos en lo que dice la Ley 1480 y el análisis de la Corte Constitucional; traguemos entero y concluyamos que toda persona que contrata con una entidad vigilada es un consumidor financiero sin importar si es una entidad financiera del exterior o una multinacional o una compañía con ventas por más de diez mil millones de pesos o una persona pensionada, y preguntémonos lo siguiente, parodiando el último mandamiento establecido en la Granja de Orwell:

Ya en el mundo en el que todos somos consumidores financieros, ¿hay unos clientes o usuarios que son "más" consumidores financieros que otros? 


\section{Los elementos para establecer distintas categorías de consumidores financieros}

A nuestro juicio, sí hay elementos que permiten categorizarlos. De por sí ello se ha hecho:

1. Desde la Resolución 400 de 1995 de la antigua Superintendencia de Valores (en su título V, parte primera), pasando por el Decreto 1121 de 2008 que subrogó aquella, se establecieron las categorías de "cliente inversionista" e "inversionista profesional", definiciones que quedaron incluidas en el Decreto Único (el “Decreto Único" o "DU”) en sus artículos 7.2.1.1.2 y 7.2.1.1.4 ${ }^{[19]}$.

La Resolución 400 de 1995 fue derogada el 15 de julio de 2010 por el artículo 12.2.1.1.4 del DU y su contenido fue recogido y reexpedido por el mismo. Ahora: si se tiene en cuenta que la promulgación de la Ley 1328 fue el 15 de julio, pero de 2009, y que los artículos de protección al consumidor financiero, los cuales van desde el 1 al 22, entraron en vigor el 10 de julio de 2010, se concluye que el Gobierno estableció esas categorías ya bajo la vigencia de la Ley 1328.

Por ende, en el mercado de valores las nociones de "cliente inversionista" e "inversionista profesional" son subcategorías dentro de la categoría de "consumidor financiero".

Así las cosas, los "inversionistas profesionales” son consumidores financieros del sector bursátil que, por cumplir con ciertas características, tal como lo dice el DU, "cuentan con la experiencia y [los] conocimientos necesarios para comprender, evaluar y gestionar adecuadamente los riesgos inherentes a cualquier decisión de inversión", calidad que hace que puedan acceder a ciertos productos o que no necesiten, por ejemplo, una asesoría tan profunda como la que debe darse a los "clientes inversionistas" 20 .

Pero ¿por qué la ley establece categorías de consumidores financieros en el mundo del mercado de valores?

A nuestro juicio, ello busca reconocer que unos consumidores financieros deben recibir más información y protección, pues tienen menos capacidad de negociación o conocen o entienden menos de los contratos propios del mercado de valores que están celebrando con las entidades vigiladas, en comparación con otros, quienes además los pueden estar manejando reiteradamente. 
Es obvio: pretender proteger a un consumidor financiero del tipo "inversionista profesional" como si fuera un inexperto que nunca ha hecho una inversión en el mercado de valores no es solo ineficiente e innecesario, sino que desestimula la inversión. Es engorroso.

En conclusión: como lo ha dicho la Corte Constitucional, y a manera de ejemplo la sentencia C-081 de 2014 (MP: Nilson Pinilla), "la igualdad se predica entre iguales y la diferencia entre diferentes".

La pregunta que nos queda es si en el sector financiero, tal como se reconoce en el mercado de valores, hay unos consumidores financieros que podrían contar "con la experiencia y [los] conocimientos necesarios para comprender, evaluar y gestionar adecuadamente los riesgos inherentes" al manejo de los portales virtuales o de los contratos de cuentas de ahorro o corrientes. ¿Será que, volviendo a los consumidores financieros que tenemos como ejemplo, Carmenza Martínez cuenta con esa experiencia y conocimiento, o más bien será que sí cuentan con esa experiencia y conocimiento Vigicol, Medicare o JF Duncan Ltd.?

Saquen sus conclusiones.

2. El Decreto 1357 de $2018^{[21]}$, sobre financiación colaborativa, contenido en el libro 41 de la parte 2 del Decreto Único, diferencia entre "aportantes calificados" y "aportantes no calificados", aplicando un criterio similar al anterior en cuanto a qué inversiones y hasta qué monto pueden hacer unos y otros.

3. La normativa de inversionistas en fondos de capital privado (FCP), establecida en el Libro 3 de la Parte 3 del DU a partir del Decreto 1984 de 2018 ${ }^{[22]}$, indica en el artículo 3.3.8.5.1 que "además de los expresamente pactados en el reglamento y de aquellos asignados por normas especiales, por las normas de protección al consumidor financiero y por las normas de protección a los inversionistas en el mercado de valores, los inversionistas o los beneficiarios designados por ellos, tendrán los siguientes derechos: [...] 6. Recibir un trato igualitario cuando se encuentre en igualdad de circunstancias objetivas con otros inversionistas del mismo fondo de capital privado". De lo cual se puede concluir:

(a) Que los inversionistas en los FCP quedan cobijados en su protección por las normas de protección al consumidor financiero y por las normas de protección a los inversionistas en el mercado de valores, y que deben recibir un trato igualitario cuando se encuentren en igualdad de circunstancias objetivas con otros inversionistas del mismo fondo. 
(b) Que las sociedades que solo administren FCP no están obligadas a tener Defensor del Consumidor Financiero (DCF), y que en caso de tenerlo, por ser administradoras de fondos de inversión colectiva, las funciones del DCF no se aplicarán a los FCP que administren, por disponerlo así el artículo 3.3.8.5.2.

Respecto de esta norma, surgen varias preguntas que, si bien no son el objeto de estudio de este trabajo, impactan el ejercicio de analogía que estamos haciendo acá. Antes, es importante dejar claro a quiénes están dirigidos los FCP: su artículo 3.3.2.2.3 indica que la participación mínima de un inversionista debe ser de 600 salarios mínimos legales mensuales vigentes, esto es $\$ 496.869 .600$, o0 para el año 2019.

No cualquier persona tiene casi 500 millones de pesos para andar invirtiendo. Incluso la SFC manifestó, cuando conceptuó sobre el tema estando vigente el régimen de FCP del Decreto 2175 de 2010, que "Con fundamento en las normas señaladas y acogiendo la calidad de inversionista citada en el concepto 2008044582003-000, un inversionista de FCP debe reunir las características de experiencia y conocimiento de mercados financieros o del campo específico en el que se gestionará el fondo, al tiempo que debe contar con la suficiente solvencia patrimonial"23.

Entonces:

- ¿Los inversores en los FCP son consumidores financieros o no lo son? Al punto que esta norma tuvo que equipararles los mismos derechos de aquellos. Es más: ¿una entidad vigilada que invierta en un FCP tiene esa protección "equivalente"?

- ¿Los inversionistas del mercado de valores son consumidores financieros o no?

Lo anterior por cuanto la norma pareciere indicar que el régimen de protección al consumidor financiero es distinto del régimen de protección al inversionista en el mercado de valores al hacer referencia a ambos por separado. Si esto fuera así, la amplitud del régimen de protección al consumidor financiero, basado en quien "contrata" con una entidad vigilada y que cubre también el mercado de valores, tendría situaciones no cobijadas. Es más: ¿el inversionista de un fondo de capital privado o FCP se equipararía al cliente inversionista o al inversionista profesional creados desde la Resolución 400 de 1995? 
- Dependiendo de las respuestas a los interrogantes anteriores, hay una pregunta igual de interesante: ¿hay personas que siendo consumidores financieros pueden no ser sujetos de protección por el DCF?

Para responder esta pregunta vale tener en cuenta que el artículo 14.J de la Ley 1328 permite al Gobierno Nacional exceptuar asuntos del conocimiento del consumidor financiero, y el artículo 13 permite al Gobierno establecer casos en que una entidad vigilada no tenga obligación de tener un DCF.

4. Pero no solo tenemos clasificaciones de consumidores según características reales, también tenemos estándares basados en clasificaciones teóricas de consumidores. A manera de ejemplo, la clasificación de consumidor medio, racional, etc., utilizada en el análisis de casos en materia de publicidad engañosa.

Este es un criterio que se ha manejado desde tiempo atrás con fines de confusión marcaria y publicidad engañosa; respecto de él, dice la Superintendencia de Industria y Comercio:

[...] el consumidor racional es la persona que interpreta la publicidad en la forma natural en la que le es transmitida, sin darle a las palabras e imágenes un alcance distinto del que naturalmente tienen, e interpretándolas en una forma superficial, sin realizar un análisis profundo o detallado, tal como lo haría una persona que no tiene un conocimiento especializado del producto o servicio anunciado ${ }^{24}$.

En ese sentido, para evaluar si la publicidad es engañosa debemos remitirnos a la interpretación que un consumidor medio realizaría, pues es aquella que busca entender el contenido y las afirmaciones en forma natural y obvia, tal como la mayoría del público a la que se dirige la publicidad lo haría. Por el contrario, una interpretación absurda, irracional o descabellada que realice una persona no será aquella a tener en cuenta, pues no representa el entendimiento general que los consumidores le dan a los anuncios ${ }^{25}$.

Por otra parte, la sección primera de la Sala de lo Contencioso Administrativo del Consejo de Estado indicó:

En sentencia del 2 de octubre de 2003, MP: Urueta Ayola (2001-016744), que: "Finalmente, la clase de consumidor y su grado de atención al momento de diferenciar, identificar y seleccionar el producto, debiéndose considerar que el consumidor al

Superintendencia de Industria y Comercio, Guía del consumidor de la Superintendencia de Industria y Comercio. 
que debe tenerse en cuenta para establecer el posible riesgo de confusión entre marcas, es el llamado 'consumidor medio' o sea el consumidor común y corriente de determinada clase de productos, en quien debe suponerse un conocimiento y una capacidad de percepción corrientes [...]".

En sentencia del 17 de marzo de 2011, MP: Lafont Pianeta, (2001-00390-01), que "También deberá considerarse la clase de consumidor o usuario y su grado de atención al momento de diferenciar, identificar y seleccionar el producto deseado. Esto a su vez se encuentra relacionado con el grado de atención que presta la persona al momento de realizar su elección, lo que dependerá del tipo de consumidor, a saber, conforme a la doctrina: a) el profesional o experto, b) elitista y experimentado, c) el consumidor medio.

"A juicio del Tribunal, 'el consumidor al que debe tenerse en cuenta para establecer el posible riesgo de confusión entre dos marcas, es el llamado 'consumidor medio' o sea el consumidor común y corriente de determinada clase de productos, en quien debe suponerse un conocimiento y una capacidad de percepción corrientes [...]'."

Por su parte, el Tribunal de Justicia de la Comunidad Andina, en Decisión del 24 de marzo de 1995 (Proceso n. ${ }^{\circ}$ 09-IP-94), en donde hizo una interpretación prejudicial a partir de solicitud del Consejo de Estado, respecto de los artículos 56, 58, literal f, y 84 de la Decisión 85 de la Comisión del Acuerdo de Cartagena, con respecto a los artículos 69 y 73 de la Decisión 85, 88 y 103 de la Decisión 313 y artículos 99 y 114 de la Decisión 344, indicó:

La jurisprudencia española en esta materia, se refiere "al consumidor medio" o "al público medio", a quien le califica como a "una persona dotada de las normales facultades perceptivas" o "a personas de raciocinio normal" quien por lo general no es una persona conocedora y diligente, que se "guía por sencillas apreciaciones visuales o auditivas corrientes".

Frente a este tipo de consumidor medio o "promedio" sale a luz el consumidor profesional y especializado, el que por su propia formación está expuesto al riesgo de confusión en menor grado que el consumidor medio o corriente ${ }^{26}$.

Por último, en sentencia del Tribunal Superior de Bogotá (Sala Civil), del 24 de septiembre de 2019, MP: Sosa Romero, expediente 11001319900120175251 01 , este, al analizar la conducta de un consumidor del sector real que demandó el cumplimiento de una publicidad de un concesionario del sector automotriz -que consideró engañosa- pues el concesionario se negó a venderle una camioneta 4 x 4 en nueve millones cien mil pesos $(\$ 9.100 .000,00)$ como decía la publicidad, 
indicó, a la hora de analizar la información y la publicidad engañosa que "debe tenerse en cuenta la noción de consumidor medio o racional, y que para el Tribunal de Justicia de la Comunidad Europea, en su jurisprudencia refiere como '[...] un consumidor medio, normalmente informado'. A la idea de consumidor medio se asocia la normalidad del nivel de información (de conocimientos). Por supuesto, no se trata de que el consumidor posea un determinado nivel académico o cultural, sino que cuente con cierta experiencia y aptitud para interpretar la información que se le facilita sobre los productos y las condiciones en las que éstos se comercializan".

No estamos sugiriendo que se clone sin pensar una teoría de otra arista del derecho a la protección del consumidor en materia financiera, sino señalar que existen los elementos legales, financieros y jurisprudenciales suficientes para que los jueces en materias de protección al consumidor financiero desarrollen (1) subcategorías de consumidores financieros en materia de productos bancarios, tal como existe en el mercado de valores, o al menos (2) para que establezcan estándares de consumidores financieros "medios" o "racionales" con los que se puedan comparar las actuaciones de los consumidores financieros en la práctica.

Quizás algunos consideren que esta "categorización" de consumidores financieros es entendible en el mercado de valores (pues los ejemplos de "clientes inversionistas", "inversionistas profesionales", "aportantes no calificados" y "aportantes calificados" son propios de ese mercado); sin embargo, nuevamente los hechos y el deber ser-que es lo que debe basar la regulación de toda ley- demuestran que también en la contratación de productos y servicios del mercado intermediado o bancario, no solo en temas de mercado de valores, hay personas con mayor o con menor conocimiento sobre lo que están contratando y con mayor capacidad para entender y cumplir las obligaciones a su cargo, como las pasaremos a estudiar.

Nuevamente, no pretendemos implantar el análisis de otra rama del derecho, solo cuestionar que sí pueden categorizarse los consumidores financieros y exigir más a unos que a otros entre ellos a partir de elementos legales y jurisprudenciales.

Pretender entonces que todos sean tan legos como Carmenza Martínez, como lo hace la Ley 1328 , es desconocer la realidad.

\section{¿Tienen obligaciones los consumidores financieros?}

1. Aplicando el mismo criterio de literalidad hecho por la Delegatura de Protección al Consumidor Financiero de la SFC en la interpretación de la Ley 1328 de la 
Delegatura de Protección del Consumidor Financiero de la SFC del 25 de noviembre de 2013 (oficio con radicación número 2013075203), concluimos que los consumidores financieros no tienen obligaciones a su cargo derivadas de su naturaleza de consumidores financieros.

Cosa distinta es que las tengan como cuentahabientes o fideicomitentes, pero ya son obligaciones derivadas de la regulación legal para esos contratos 0 de las regulaciones establecidas en esos mismos contratos. No de la categoría de consumidores financieros.

Suena insólito.

La Ley 1328, que es el régimen de protección al consumidor financiero, es decir, donde se supone se encuentra todo lo regulado en esa materia, establece en sus artículos 5 y 6 (1) los "derechos" de aquellos y (2) una nueva categoría que se denomina "prácticas de protección propia por parte de los consumidores financieros".

Dos ejemplos de estas prácticas son los siguientes:

Artículo $6^{\circ}$. Prácticas de protección propia por parte de los consumidores financieros. Las siguientes constituyen buenas prácticas de protección propia por parte de los consumidores financieros:

$[\ldots]$

(b) Informarse sobre los productos o servicios que piensa adquirir o emplear, indagando sobre las condiciones generales de la operación; es decir, los derechos, obligaciones, costos, exclusiones y restricciones aplicables al producto o servicio, exigiendo las explicaciones verbales y escritas necesarias, precisas y suficientes que le posibiliten la toma de decisiones informadas.

(c) Observar las instrucciones y recomendaciones que imparta la entidad vigilada sobre el manejo de productos o servicios financieros.

Si el legislador hubiera querido establecer "obligaciones" para los consumidores financieros, hubiera establecido un título de "obligaciones" para ellos, como lo ha hecho desde hace más de cien años. De hecho, así lo hizo para las entidades vigiladas en su artículo 7.․

Es más: al revisar la exposición de motivos en los antecedentes legislativos de la Ley 1328 en la Gaceta del Congreso n. ${ }^{\circ}$ 138, del 11 de abril de 2008, hay una extraña e insólita confusión en cuanto al entendimiento de lo que es una "obligación", un "deber" y ahora una "práctica de protección propia", pues a pesar de establecer en el título la expresión "obligaciones" lo que se desarrollan son esas "prácticas de protección propia" en el caso de los consumidores financieros: 
$[\ldots]$

2. Los derechos y obligaciones.

El proyecto de reforma financiera establece un compendio de derechos de los consumidores financieros, sin perjuicios de los derechos consagrados en otras disposiciones vigentes.

Dentro de los principales derechos listados en el proyecto se encuentran el de recibir de parte de las entidades vigiladas productos y servicios oportunos y con altos estándares de calidad [...]

De igual manera se establece un conjunto de buenas prácticas de protección propia por parte del consumidor, entre las cuales podemos destacar: Verificar que la entidad se encuentre autorizada por la SFC; indagar sobre las condiciones generales de la operación; informarse respecto de los productos o servicios que pretenda adquirir o usar $[\ldots]$.

Sin embargo, a nuestro juicio el incentivo generador del riesgo moral, esto es, una situación en la que "un individuo tiene información asimétrica acerca de las consecuencias de sus propias acciones y sin embargo son otras personas las que soportan las consecuencias de los riesgos asumidos" 27 , de manera que "los individuos asumen en sus decisiones mayores riesgos cuando las posibles consecuencias negativas de sus actos no son asumidas por ellos, sino por un tercero" 28 , es el siguiente, también establecido en el parágrafo de ese mismo artículo:

Parágrafo 1. El no ejercicio de las prácticas de protección propia por parte de los consumidores financieros no implica la pérdida o desconocimiento de los derechos que le son propios ante las entidades vigiladas y las autoridades competentes. De igual manera, no exime a las entidades vigiladas de las obligaciones especiales consagradas en la presente ley respecto de los consumidores financieros.

Sin embargo, es más que entendible que el anterior parágrafo se aplique a algunas clases de consumidores financieros, como son, por ejemplo, las personas naturales (v. gr., Carmenza Martínez), pero al no tener esta claridad, la Ley 1328 termina invitando a los consumidores financieros distintos de personas naturales, sean pymes o grandes empresas o multinacionales o establecimientos financieros del exterior que contratan productos financieros en Colombia, a no informarse sobre los contratos que celebran y a no observar las instrucciones y recomendaciones. Reverté, 2007), 449. Ídem. 
Un "consejo" que no compartimos.

En todo caso, debemos destacar que el tener en cuenta las características especiales de quien se predica la calidad de consumidor financiero, es un asunto que en teoría debería ser tenido en cuenta por el juez en su análisis del caso en materia de protección al consumidor en fraude electrónico. Al menos ello se deduce en principio en el módulo de aprendizaje sobre el sistema financiero y bursátil de la Escuela Judicial Rodrigo Lara Bonilla:

Ahora bien, en Colombia se ha adoptado la doctrina por medio de la cual el consumidor presenta una división en sus características. En razón a las características especiales su responsabilidad y protección pueden variar:

Alrededor de este concepto giraron los derechos del consumidor y su protección, noción progresivamente decantada luego de desecharse la clasificación productor (especialista) - consumidor (profano), hasta llegar a suponer como consumidor, (1) al destinatario final, que mediante (2) un acto de consumo, busca (3) la satisfacción de una necesidad intrínseca, (4) no en el ámbito de una actividad económica propia, reubicándose el desequilibrio en la relación productor o expendedor, de una parte, y consumidor, de la otra ${ }^{29}$.

Pero hagamos otro análisis a partir de lo dispuesto en este insólito parágrafo para consumidores distintos a Carmenza Martínez: también hay un riesgo moral, como lo indican otros autores ${ }^{30}$, cuando “la acción (o mejor, la 'inacción' en observar las instrucciones y recomendaciones de seguridad para el manejo del portal) del agente que escoge espontáneamente (el consumidor), no es igualmente óptima para el agente y para el 'principal' (entiéndase el banco)", esto porque "como la acción no es observable por el principal, el principal no puede obligar al consumidor a elegir una acción (cumplir las instrucciones) que sea óptima para ambos. Solo puede influir en la elección de acción del agente condicionando la utilidad del agente a la única variable que es observable: el resultado. Esto a su vez solo se puede hacer dando al agente una transferencia que depende del resultado".

Sin embargo, en el caso en concreto, además de que el banco no puede saber si un consumidor financiero está cumpliendo con las instrucciones de seguridad (Bogotá: Imprenta Nacional, 2019), 94.

30 Traducción libre de "Because the action is unobservable, the Principal cannot force the Agent to choose an action that is Pareto-optimal. He can only influence the choice of action by the Agent by conditioning the Agent's utility to the only variable that is observable: the outcome. This in turn can only be done by giving the Agent a transfer that depends on the outcome". Bernard Salanié, The Economics of Contracts (London: MIT, 2005), 1063. 
( $v$. gr., el banco no tiene un funcionario al lado del consumidor verificando si presta la clave), el banco no puede usar la herramienta que acá se menciona de no proveerle al consumidor el resultado si no las cumple; es decir, no puede decirle al consumidor que si no cumple con ello le termina el contrato o le bloquea el servicio del portal por un rato o que en caso de fraude por no cumplir esas instrucciones es su responsabilidad. Ello podría ser considerado un comportamiento abusivo en los términos del capítulo 1 , título 3, parte 1 de la $C B$ J, pues técnicamente, según este parágrafo, el consumidor financiero puede no "observar" esas instrucciones y aun así el banco estar llamado a responder en ese caso $^{31}$.

Queda entonces en evidencia que lo que era obvio y necesario para proteger adecuadamente a aquellos consumidores financieros sin educación, sin medios cognoscitivos suficientes para leer un contrato de cualquier producto financiero o para entender unas recomendaciones, termina generalizándose y aplicándose para personas que sí tienen todos esos medios para leer, informarse, observar y aplicar para su propia protección.

En síntesis: la igualdad aplica acá también a quienes no son iguales.

Habiendo puesto en evidencia el problema y en aras de concretar esta crítica constructiva, nos atrevemos a sugerir una redacción, obviamente también criticable, para no seguir tratando igual a quienes no son iguales ni invitando a no informarse o no seguir recomendaciones a quienes sí tienen la posibilidad -y la capacidad jurídica y económica- de informarse y seguirlas:

Parágrafo 1. El no ejercicio de las prácticas de protección propia por parte de los consumidores financieros no implica la pérdida o desconocimiento de los derechos que le son propios ante las entidades vigiladas y las autoridades competentes. Las autoridades administrativas y judiciales analizarán las características particulares del consumidor financiero cuando este sea una persona jurídica, por ejemplo, su naturaleza, tamaño económico, experiencia y conocimiento en temas financieros, bursátiles y aseguradores, etc. a la hora de aplicar este parágrafo.

Y como, quizás, lograr establecer esto en una ley, en tiempos en que en Colombia todos hablan de derechos pero nadie de responsabilidades, es un imposible político, consideramos que es importante insistir en cada oportunidad en hacer

31 Algunos ejemplos de lo que podría ser una cláusula o comportamiento abusivo si el banco hiciera algo de esto son las siguientes: (1) Son cláusulas abusivas, aquellas que exoneren o atenúen los deberes y responsabilidades propios del objeto social de las entidades vigiladas (6.1.4); (2) Son cláusulas abusivas, aquellas que afectan el equilibrio contractual o dan lugar a abuso de posición dominante contractual (6.1.6); y (3) Es un comportamiento abusivo el obligar al consumidor financiero a certificar que se encuentra en un computador seguro (6.2.49). 
notar al operador jurídico estas diferencias de consumidores y exigencias para que ojalá, algún día, se construya una jurisprudencia que reconozca esta realidad.

\section{A) ¿Dónde están entonces nuestras obligaciones como consumidores financieros?}

Consideramos que en leyes específicas y en los contratos que regulen los productos o servicios que contratamos con entidades vigiladas, por ejemplo, los artículos 1382 y siguientes del Código de Comercio para la cuenta corriente bancaria, o en los textos de los mismos contratos que los soportan y que en ocasiones deben ser enviados a la SFC para su revisión, como por ejemplo los de los depósitos de ahorro.

$Y$, a nuestro juicio, en el cumplimiento de esas obligaciones sí se debería analizar (1) quién es concretamente la persona que está en el papel de consumidor financiero y (2) cuál es el grado de dificultad en el cumplimiento de cada obligación que tiene ese consumidor financiero bajo el contrato que celebró.

Es decir, proponemos que la categorización de consumidores financieros arriba explicada no solo sirva para brindarles más protección e información a unos que a otros, lo cual es plenamente sensato, sino que también sea un criterio para poderles exigir más a un tipo de consumidor financiero que a otro acorde con quién es.

Hagamos una matriz con ejemplos de obligaciones usuales para el manejo de un portal virtual:

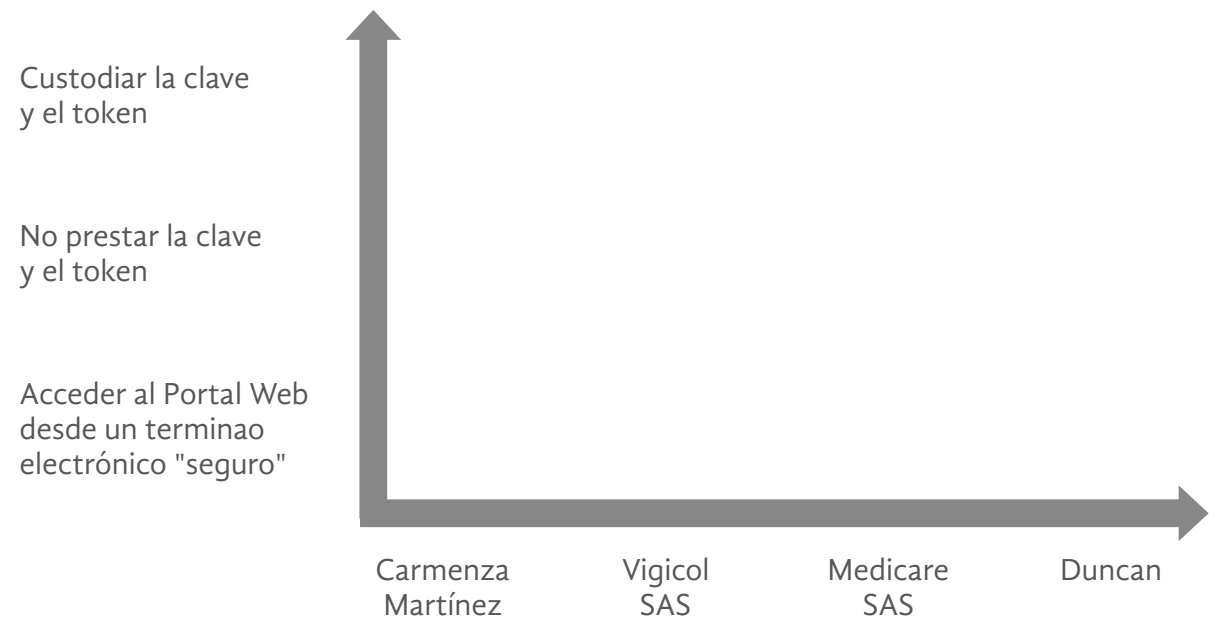


Personalmente, por más que se diga o se explique cada una de esas obligaciones en el contrato que celebre Carmenza Martínez para manejar el portal virtual, consideramos que el entendimiento de ellas puede serle bastante difícil. No porque dudemos de sus capacidades cognoscitivas sino porque somos conscientes de que simplemente ella no leerá el contrato, situación de hecho que explica el parágrafo 1 del artículo $6 .^{\circ}$, o que, si lo lee, no lo entienda del todo.

Pero en cambio consideramos, y suponemos, que Vigicol, una compañía de seguridad, sí debería tener un poco más claro que Carmenza Martínez lo que significa custodiar la clave y el token o no usar el mismo computador que usa para entrar al portal empresarial para visitar sitios de dudosa reputación y de alta estimulación, pues por sentido común (o a partir de las "reglas de la experiencia" de las que se nos hablan en derecho procesal) dudo que una empresa llegue a ser una compañía de seguridad de ese tamaño si durante su existencia se ha caracterizado por manejar folclóricamente sus dineros sin una adecuada vigilancia o dejando estas "llaves" de entrada a su "alcancía" al alcance de cualquier paisano.

Ni qué decir de Medicare o Duncan.

Lo anterior no es extraño; de por sí, cualquier libro o sitio de internet sobre ciberseguridad termina dando los mismos consejos que se dan en el mundo real: no hable con extraños, no preste las llaves de su casa a extraños, no camine por calles oscuras... ${ }^{32}$.

Es más: según estudios citados por quienes se dedican al tema de seguridad informática, "más del $75 \%$ de los problemas inherentes a la seguridad se producen [por] fallos en la configuración de los equipos o debido a un mal uso por parte del personal de la propia organización" ${ }^{\prime 3}$.

\section{El primer eje de la matriz. ¿Quién es concretamente la persona que está en el papel de consumidor financiero? ¿Hay estándares contra los cuales se puede comparar?}

Aunado a lo anterior, consideramos que al estudiar un régimen de responsabilidad en materia de protección se podría tener en cuenta otras particularidades de los

"10 consejos para navegar seguro por internet": www.infospyware.com, acceso el 9 de septiembre de 2019, https://www.infospyware.com/articulos/10-consejos-para-navegar-seguro-por-internet/; "10 consejos de seguridad para usuarios digitales": www.uoc.edu, acceso el 9 de septiembre de 2019, https://www.uoc.edu/portal/es/news/actualitat/2016/022-consejos-seguridad-internet.html; "Día del internet: consejos para mejorar la seguridad al navegar": www.revistabyte.com, acceso el 9 de sep tiembre de 2019, https://www.revistabyte.es/seguridad-informatica/dia-de-internet-seguridad/. 
consumidores financieros, pues hay personas naturales, personas jurídicas, microempresas, pymes, grandes empresas, comerciantes, no comerciantes, sociedades de economía mixta, sociedades de servicios públicos, quienes ejercen profesiones liberales, pensionados, etc.

Y a partir de ello, a la hora de verificar el estándar o medida de valoración del cuidado exigible a cómo cumplen ellos con sus obligaciones podríamos acudir a una categoría del consumidor financiero "medio" como la ya explicada, o analizar su responsabilidad comparando sus actuaciones versus dos estándares: el buen padre de familia en el marco civil (artículo 63 del Código Civil) y el buen hombre de negocios en el marco comercial respecto de los administradores de las sociedades (artículo 23 de la Ley 222 de $1995^{[34]}$ ).

Estas calidades no se contradicen con la de consumidor financiero pues no fueron derogadas por la Ley 1328 sino que se complementan. Es apenas obvio: un comerciante no deja de ser comerciante por el hecho de ser ahora también un consumidor financiero.

Es más: si reconocemos que la Ley 1480 llena ciertos vacíos de la Ley 1328 a partir de lo dispuesto en el segundo párrafo del artículo $2 .^{\circ}$ de la Ley 1480 , uno de los artículos que entran a aplicarse es el artículo 4 de esta ley, el cual dispone que "en lo no regulado por esta ley, en tanto no contravengan los principios de la misma, de ser asuntos de carácter sustancial se le aplicarán las reglas contenidas en el Código de Comercio y en lo no previsto en este, las del Código Civil".

Podríamos aceptar que la noción de buen hombre de negocios se aplica al ser la Ley 222 parte de la legislación mercantil -si se entiende que la expresión "Código de Comercio" debe hacer referencia a la legislación mercantil-, o como el desarrollo en el mundo mercantil del estándar del buen padre de familia dispuesto en el artículo 63 del Código Civil colombiano.

Valga anotar que en la sentencia del Tribunal Superior de Bogotá del 24 de septiembre de 2019 ya citada ${ }^{35}$ se reconoció la aplicación de este artículo al estudiar el caso para traer al análisis las normas sobre la oferta mercantil contenidas en el Código de Comercio.

¿Pero son iguales estos estándares, el "buen padre de familia" y el "buen hombre de negocios"? La respuesta mayoritaria es "no"36, pues al buen hombre

Ley 222/1995.

Tribunal Superior de Bogotá, expediente 11001319900120175251 01, sentencia del 24 de septiembre de 2019, MP: Julián Sosa Romero.

Si bien Fernando Silva considera que ambas categorías hacen referencia al mismo grado de diligencia. Fernando Silva García, "Régimen de responsabilidad de los administradores de instituciones 
de negocios se le puede exigir más en el cumplimiento de sus obligaciones que al buen padre de familia. Al respecto, la Corte Constitucional, en la sentencia C-123 de 2006, MP: Vargas Hernández, indicó:

Cabe recordar que la Ley 222 de 1995 impuso a los administradores un grado de diligencia y prudencia superiores a la mediana que hasta entonces tenía, la de un buen padre de familia, pues ahora deberán actuar con la diligencia propia de un buen hombre de negocios, es decir, con la que pondría un comerciante normal en sus propios asuntos, lo que supone una mayor exigencia en la administración de los asuntos propios de la sociedad.

Y en 2013 la Superintendencia de Sociedades conceptuó ${ }^{37}$ :

La diligencia de un buen hombre de negocios hace relación a que las actuaciones de los administradores no sólo deben encontrarse acompañadas de la prudencia de un buen padre de familia, sino que su diligencia debe ser la que tendría un profesional, un comerciante sobre sus propios asuntos, de manera que su actividad siempre debe ser oportuna y cuidadosa, verificando que la misma esté ajustada a la ley [...]. La diligencia del buen hombre de negocios, lleva implícitos deberes como el de informarse suficientemente antes de tomar decisiones.

Por tanto, es lógico desde el punto de vista jurídico que a los administradores de Vigicol, a Medicare y a Duncan, quienes son al final de cuentas quienes negocian los contratos que celebran con los bancos y quienes los ejecutan o delegan su ejecución, les podamos exigir más, en el cumplimiento de las obligaciones de los contratos financieros que celebren con entidades vigiladas que lo que le exigiríamos a Carmenza Martínez y a partir de ello poder comparar su comportamiento contra un estándar de diligencia distinto.

Desconocerles sus calidades específicas de comerciantes y el "deber ser" del comportamiento de sus administradores en cuanto a prudencia y diligencia implicaría: (1) concluir que lo que se puede esperar de un comerciante profesional y el estándar de buen hombre de negocios de este se contradice con el régimen de protección al consumidor; (2) concluir que dichas categorías son excluyentes con la de consumidor financiero; y (3) equiparar (¿igualar?) bajo la categoría de consumidor financiero, en una ficción errada, al comerciante más conocedor del

financieras", Revista de Derecho Privado, n. ${ }^{\circ} 4$ (1999): 69, https://revistas.uexternado.edu.co/index. php/derpri/article/view/665. 
mundo de los negocios, de quien se puede esperar mucho en el cumplimiento de sus obligaciones, con la persona y no comerciante más desconocedora de aquél.

Ahora bien: algunos, a manera de crítica, podrían indicar que generalizar la noción de "buen hombre de negocios" para toda persona jurídica de derecho privado implica igualar en una misma categoría a personas jurídicas muy dispares, pues dentro de las sociedades hay microempresas, pymes, grandes empresas, etc., y muchas clasificaciones establecidas también dentro del sector financiero basadas, por ejemplo en el tamaño patrimonial y las ventas anuales. A partir de esto, sugeriríamos que el análisis de responsabilidad tuviera en cuenta esa realidad, más aún cuando hay normas legales que reconocen diferencias como esas a la hora de apoyar o legislar sobre un tipo de empresas específico, como la Ley 905 de $2004^{[38]}$, sobre desarrollo de la micro, pequeña y mediana empresa.

Una cuestión adicional: a futuro puede que las nociones de "buen padre de familia" y "buen hombre" de negocios sean reemplazadas por el estándar de la deferencia empresarial basado en la "persona razonable", propio del mundo anglosajón, o por razones de igualdad de género, como sucedió en Francia con la ley 2014-873. De por sí, la Superintendencia de Sociedades propuso tiempo atrás reformas societarias con ese enfoque ${ }^{39}$ y el Código Civil y Comercial de la Nación de la República Argentina en su artículo 1710 ya sigue el criterio de razonabilidad ${ }^{40}$. Derivado de ello encontramos al menos estos cambios:

- La noción de deferencia empresarial está basada más en establecer un criterio de responsabilidad interno de los administradores ante los accionistas de la sociedad, no hacia terceros. Siendo así, sería más difícil aplicar esta nueva noción en campos ajenos al derecho societario como sería en el financiero.

- La noción de razonabilidad ha tenido en el derecho anglosajón una evolución desde hace más de cien años. De por sí, al primigenio "duty of reasonable care" se le cita como punto de partida el caso de Vaughan v. Menlove de 1837 evolucionando a la "reasonable diligence", el "reasonable price", etc. ${ }^{41}$. Trasplantar toda una teoría jurídica de un plumazo

Ley $905 / 2004$.

Cámara de Representantes, Proyecto de Ley n. 70 de 2015.

Código Civil y Comercial de la Nación, Argentina.

Gema Tomás Martínez, “La sustitución del «buen padre de familia» por el estándar de la «persona razonable»: reforma en Francia y valoración de su alcance", Revista de Derecho Civil 2, n. ${ }^{\circ} 1$ (2015): 57, https://www.nreg.es/ojs/index.php/RDC/article/view/109/89. 
sin ningún desarrollo jurisprudencial previo generaría vacíos notorios o que los jueces sigan aplicando los criterios de los estándares que ya conocen, y que entiendan que esto es un cambio meramente formal.

- La necesidad del derecho continental de concretar lo que es "razonable" seguramente hará que se defina el término. Así sucedió con los Principios europeos de derecho contractual, en cuyo artículo 1:302 (ex art. 1.108) se indicó que "Según estos Principios, la razonabilidad debe ser juzgada por lo que las personas que actúan de buena fe y en la misma situación que las partes consideran razonable. En particular, al evaluar lo que es razonable se deben tener en cuenta la naturaleza y el propósito del contrato, las circunstancias del caso y los usos y prácticas de los oficios o profesiones involucradas" ${ }^{\prime 2}$.

Insistimos, una modificación al parágrafo 1 del artículo $6 .^{\circ}$ de la Ley 1328 o una jurisprudencia en ese sentido podría dejar claro al operador jurídico analizar en cada caso quién es el consumidor financiero en sí a la hora de estudiar cómo fue el cumplimiento de sus obligaciones y las de la entidad vigilada en el caso en concreto.

Es más: un estándar de diligencia no es extraño para estos temas, y por ende se podría aplicar para ambos lados. En el fallo de la Sala de Casación Civil de la Corte Suprema de Justicia (CSJ) del 19 de diciembre de 2016 (SC 18614-2016), MP: Salazar Ramírez ${ }^{43}$, considerada para algunos doctrinantes la sentencia más "representativa en materia de fraude electrónico" ${ }^{44}$, la Corte acogió los análisis hechos por el Tribunal Superior de Medellín para dictar la sentencia de segunda instancia basados, en ese momento, en el artículo 98 del Eosf (modificado por la Ley 795 de 2003) y el 72, referente a las reglas de conducta de los administradores, para concluir entonces que

Como el sentido de las normas no se alteró, quiere decir que las conclusiones del sentenciador de que la «debida diligencia» exigida era «la de un profesional que deriva provecho económico de un servicio en el que existe un interés público» y que la responsabilidad por no cumplirla en forma solo se resquebraja «si por culpa

Traducción libre a partir de: "Under these Principles reasonableness is to be judged by what persons acting in good faith and in the same situation as the parties would consider to be reasonable. In particular, in assessing what is reasonable the nature and purpose of the contract, the circumstances of the case, and the usages and practices of the trades or professions involved should be taken into account". University of Oslo, The principles of the European contract law, 2002. diciembre de 2016, MP: Ariel Salazar Ramírez, 59. 
del cuenta habiente o de sus dependientes o representantes, se produce un pago o se materializa un traslado u otro tipo de operación en el que se comprometan recursos del cliente con base en fraudes», no comporta desconocimiento alguno del régimen de responsabilidad aplicable, según se destacó líneas atrás.

Acá, en pocas palabras, se propone que el juez también analice la debida diligencia esperable de un consumidor financiero cuando por ser comerciante se supone que debe actuar con la diligencia y prudencia de un buen hombre de negocios.

\section{¿Cuál es el grado de dificultad en el cumplimiento de cada obligación que tiene ese consumidor financiero bajo el contrato que celebró?}

Trataremos este punto en la segunda parte de este escrito, bajo el título "Que el consumidor financiero no cumplió las obligaciones a su cargo".

\section{SEGUNDA PARTE}

\section{Los aspectos prácticos de la protección del consumidor financiero}

Parte de este análisis lo haremos a partir de la sentencia de la Sala de Casación Civil de la CSJ del 19 de diciembre de 2016, ya citada.

Como es una sentencia de casación, una de las finalidades que cumple la Corte al dictarla, según el Código General del Proceso, es defender la unidad e integridad del ordenamiento jurídico ${ }^{45}$, para lo cual interpreta la ley. Por tanto, al revisar esta sentencia, este análisis no parte del supuesto de "lo que quiso decir la Corte Suprema" sino de "lo que dijo la Corte Suprema".

No vamos a interpretar al intérprete.

Los hechos de esta sentencia se ubican en 2007, cuando a una persona jurídica del tipo sociedad anónima le sustrajeron 124 millones de pesos de su cuenta de ahorros a través del portal de internet provisto por el banco, cuyos servicios el banco cobraba. Es de anotar que para ese momento se ingresaba al portal virtual de esa entidad con una sola clave, según se desprende de los hechos del caso. 
La Corte no casó la sentencia que condenó al banco demandado, y para el efecto hizo un análisis de la evolución de los bancos en materia de responsabilidad sobre cheques y los criterios que sustentan su responsabilidad, desde la teoría del riesgo creado, "en virtud de la cual quien en desarrollo de una actividad genere un peligro o contingencia, debe indemnizar los perjuicios que de aquel deriven para terceros, con independencia de si ha actuado de manera diligente o culposa, o de si ha obtenido o un provecho", hasta llegar a la teoría del "riesgo profesional", como derivación de la teoría del "riesgo provecho", a partir de la cual "la obligación de asumir los riesgos inherentes al ejercicio de la actividad se basa en el profesionalismo que esta requiere" ${ }^{46} \mathrm{y}$ de quien se lucra de ellos.

Al respecto, no negamos que lo anterior debe ser vital a la hora de decidir la responsabilidad del caso, pero en este trabajo nos queremos enfocar en la otra parte del contrato. Pues se supone que el contrato para la utilización del portal virtual es un contrato bilateral.

De acuerdo con esta sentencia, las entidades vigiladas son expertas en la prestación de servicios financieros, y por ende solo se exoneran en un litigio relativo a protección del consumidor si prueban en un proceso judicial iniciado por una acción de protección al consumidor financiero:

(1) que el consumidor financiero no cumplió con las obligaciones a su cargo;

(2) que la entidad vigilada sí cumplió con las obligaciones a su cargo.

Lo primero que hay que indicar es que no hay un criterio legal y objetivo para concluir qué pesa más en una balanza entre estos dos puntos a la hora de definir la responsabilidad de una entidad vigilada.

El tema no es menor y se entiende mejor identificando los escenarios:

\begin{tabular}{l|l}
$\begin{array}{l}\text { Escenario 1. La entidad vigilada prueba que el } \\
\text { cliente incumplió sus obligaciones y también } \\
\text { prueba que ella sí cumplió sus obligaciones. }\end{array}$ & $\begin{array}{l}\text { Escenario 2. La entidad vigilada prueba que } \\
\text { el cliente incumplió sus obligaciones, pero no } \\
\text { prueba que ella sí cumplió las suyas. }\end{array}$ \\
\hline $\begin{array}{l}\text { Escenario 3. La entidad vigilada no prueba } \\
\text { que el cliente incumplió sus obligaciones, pero } \\
\text { sí prueba que ella cumplió sus obligaciones. }\end{array}$ & $\begin{array}{l}\text { Escenario 4. La entidad vigilada no prueba } \\
\text { que el cliente incumplió sus obligaciones ni } \\
\text { prueba que ella sí cumplió sus obligaciones. }\end{array}$ \\
\hline
\end{tabular}

Es en los escenarios 2 y 3 donde el asunto es interesante, como adelante se explica.

46 Ibíd., 38. 


\section{Que el consumidor financiero no cumplió las obligaciones a su cargo}

1. En materia de reglamentos de portales virtuales, usualmente se establecen estas obligaciones en cabeza del consumidor financiero que contrata este servicio ${ }^{47}$ :

- Entrar desde sitios seguros, no públicos, y tampoco abriendo enlaces recibidos por correo electrónico, etc.

- Tenerle contraseña al computador con el que accede.

- Custodiar la clave.

- No descargar archivos maliciosos o virus.

- Tener contratado y actualizado un software de antivirus.

- Registrar un celular y mail para mensajes de ingresos y transacciones.

- Custodiar el mecanismo OTP o token. El OTP o "one time password" es una "contraseña de un solo uso", es decir, es "una contraseña válida solo para una autenticación". Con ella

se soluciona una serie de deficiencias que se asocian con la tradicional (estática) contraseña. La deficiencia más importante que se aborda en las OTP es que, en contraste con contraseñas estáticas, no son vulnerables a ataques de Replay. También hace al sistema más resistente frente ataques de fuerza bruta, ya que cada vez que cambia la contraseña, los intentos realizados anteriormente para romper la contraseña anterior son inútiles y hay que empezar de nuevo. Esto significa que un posible intruso que logre registrar una OTP que ya se utiliza para iniciar sesión en un servicio o realizar una transacción no será capaz de abusar de ella, puesto que ya no será válida. En el lado negativo, las OTP son difíciles de utilizar en los seres humanos, debido a que un ser humano no puede memorizar todas. Por lo tanto, se requiere de 
una tecnología adicional para funcionar" ${ }^{48}$. O, de manera resumida como las definen quienes proveen estos productos, es "una contraseña diseñada para utilizarse una sola vez. Es ideal para agregar seguridad a las contraseñas estáticas, o bien para dar acceso a un usuario que olvidó su contraseña"49.

Para efectos de estas paradojas, las preguntas que surgen y enfocándolas principalmente a personas jurídicas, no a personas naturales, a manera de ejemplo, son estas: ¿son la mayoría de estas obligaciones altamente "especializadas" o son más de "sentido común"?, ¿son de difícil entendimiento o de difícil cumplimiento?, ¿qué podemos concluir respecto de la diligencia de un consumidor financiero si se prueba que incumplió algunas de estas obligaciones, pero no se logra probar el incumplimiento de otras?

La respuesta la dejamos al lector: al final de cuentas el sentido común impera también en el mundo virtual como en el físico, pero "por desgracia-como lo anotan quienes se dedican a temas de seguridad en internet-, los usuarios no suelen estar tan concienciados de esta importancia como deberían"50.

Hacer entender esto es de vital importancia para una justa decisión sobre la protección de los recursos del público, más aún cuando se encuentra que muchas personas jurídicas de derecho privado y público de distintos tamaños, con ánimo de lucro o no, establecen en el ámbito interno códigos de conducta, manuales y políticas en materia de seguridad tecnológica en donde al final de cuentas replican las mismas obligaciones en materia de tecnología que las contenidas en los contratos con entidades vigiladas, soportando además en ellas causales de despido con justa causa.

Ahora, en la medida en que la sentencia ya mencionada de la CSJ es un hito en materia de responsabilidad bancaria en temas de fraude electrónico, pues por primera vez se aborda este tema y busca crear una jurisprudencia independiente a la basada en el mal pago de cheques, transcribimos un aparte de ella que nos genera incertidumbre sobre lo que quiso decir la Corte (páginas 56 y 57):

De ahí que atendiendo la naturaleza de la actividad y de los riesgos que involucra o genera su ejercicio y el funcionamiento de los servicios que ofrece; el interés

"Autenticación con contraseña de un solo uso", Wikipedia. La enciclopedia libre, acceso el 22 de septiembre de 2019, https://es.wikipedia.org/wiki/Autenticaci\%C3\%B3n_con_contrase\%C3\%B1 a_de_un_solo_uso.

“¿Qué es un one time password?", Auronix, acceso el 3 de junio de 2020, https://www.auronix.mx/ blog/2016/02/que-es-one-time-password. 
público que en ella existe; el profesionalismo exigido a la entidad y el provecho que de sus operaciones obtiene, los riesgos de pérdida por transacciones electrónicas corren por su cuenta (refiriéndose a las Vigiladas), y por lo tanto, deben asumir las consecuencias derivadas de la materialización de esos riesgos a través de reparar los perjuicios causados, y no los usuarios que han confiado en la seguridad que les ofrecen los establecimientos bancarios en la custodia de sus dineros, cuya obligación (refiriéndose a los usuarios) es apenas la de mantener en reserva sus claves de acceso al portal transaccional".

Desde luego que consumada la defraudación, el banco para exonerarse de responsabilidad, debe probar que esta ocurrió por culpa del cuentahabiente o de sus dependientes, que con su actuar dieron lugar al retiro de dinero de la cuenta, transferencias u otras operaciones que comprometieron sus recursos, pues amén de que es este quien tiene el control de mecanismo que le permiten hacer seguimiento informático a las operaciones a través de controles implantados en los software especializados con los que cuentan, la culpa incumbe demostrarla a quien la alegue (art. 835 C. Co.), pues se presume la buena fe "aún la exenta de culpa".

Advirtiendo que no conocemos los textos de los contratos analizados por la CSJ que generaron esa sentencia de casación, pero asumiendo que en ellos estuvieran otras obligaciones, como suele pasar en cualquier contrato, y no solo la obligación de mantener en reserva las claves de acceso al portal virtual, nos preguntamos qué quiso decir la CSJ:

¿La CSJ concluyó que si bien puede haber muchas obligaciones en cabeza del consumidor financiero en materia de seguridad electrónica, como las arriba enunciadas, la única que importa para efectos de saber si este tiene que asumir total o parcialmente la pérdida es si cumplió o no con la obligación de mantener en reserva las claves? o

¿La CSJ concluyó que si un consumidor financiero prueba que cumplió con la obligación de mantener en reserva las claves o no le prueban que incumplió ello, es indiferente que se pruebe que incumplió otras obligaciones a su cargo establecidas en el contrato, por ejemplo, el que entró a sitios de dudosa reputación o que descargó virus en los computadores que usaba para conectarse al portal virtual del banco?

Afortunadamente, el entendimiento que ha tenido la SFC en su delegatura de funciones jurisdiccionales ha sido, como se indicó en fallo del 14 de marzo de 2018, expediente 2017-034-137, es que sí importa tanto la obligación de mantener la reserva de la clave y otros mecanismos de seguridad como las otras obligaciones establecidas en el contrato como las ya mencionadas. A manera de ejemplo, en el caso Empresa Integral de Servicios OP\&S Construcciones SA ESP vs BBVA, la SFC 
concluyó la exoneración de esta última a partir de la prueba de que la demandante, entre otras cosas, tenía instalado en el computador con el que accedía al portal virtual del banco un malware o virus que permitía robar datos.

\section{A) La carga de la prueba}

Un punto adicional que se aplica en materia de protección al consumidor y que se deriva no solo de la interpretación del principio de traslado de la prueba del CGP en su artículo 167 sino de la situación de desequilibrio que hay entre la entidad vigilada y el consumidor financiero, es que a la primera le corresponde probar el incumplimiento del segundo. Por tanto, si no lo prueba, no puede exonerarse.

Ahora, la paradoja en la protección al consumidor financiero que se presenta se explica mejor con un ejemplo:

Supongamos que un cliente, para poder acceder al portal virtual, debe ingresar una clave y el además número que le arroja un token o mecanismo OTP, dos mecanismos que conforman en conjunto lo que la SFC ha denominado un "mecanismo fuerte de autenticación" en la Circular Externa 8 de 2018 (la cual quedó contenida en la parte 1 del título II del capítulo 1 de la Circular Básica Jurídica (CBJ) de la Superintendencia Financiera de Colombia, numerales 2.2.5 y 2.2.6), pues cumplen en conjunto con lo exigido al tratarse de un "Conjunto de técnicas y procedimientos utilizados para verificar la identidad de un cliente, entidad o usuario" a partir de algo que se sabe (la clave) con algo que se tiene (el token) ${ }^{51}$.

51 Superintendencia Financiera de Colombia, Circular básica jurídica. Contenida en la parte 1 del título Il del capítulo 1 de la Circular Básica Jurídica ("CBJ") de la Superintendencia Financiera de Colombia, numerales 2.2.5 y 2.2.6:

"2.2.5. Autenticación: Conjunto de técnicas y procedimientos utilizados para verificar la identidad de un cliente, entidad o usuario. Los factores de autenticación son: algo que se sabe, algo que se tiene, algo que se es.

2.2.6. Mecanismos fuertes de autenticación: Se entienden como mecanismos fuertes de autenticación los siguientes:

2.2.6.1. Biometría.

2.2.6.2. Certificados de firma digital de acuerdo a lo establecido en la Ley 527 de 1999 y sus decretos reglamentarios.

2.2.6.3. OTP (One Time Password), en combinación con un segundo factor de autenticación.

2.2.6.4. Tarjetas que cumplan el estándar EMV, en combinación con un segundo factor de autenticación.

2.2.6.5. Registro y validación de algunas características de los computadores o equipos móviles desde los cuales se realizarán las operaciones, en combinación con un segundo factor de autenticación”. 
Haciendo la analogía, esta es una puerta que tiene dos cerraduras. Por tanto, no se puede abrir si solo se tiene la llave para abrir una de ellas. Tal como pasa en el mundo real.

Entonces, en este caso, la entidad vigilada, además de probar que cumplió sus obligaciones propias, tendría teóricamente que probar que el cliente descuidó tanto la clave como el token.

Pero supongamos que la entidad vigilada decide mejorar la seguridad para sus clientes y ahora exige no una clave y un número arrojado por un token, sino que, además de estos dos mecanismos, pide una segunda clave o una pregunta de seguridad. Es decir, otro factor de autenticación basado en "algo que se sabe". Continuando con la analogía, la puerta tiene ahora tres cerraduras y se necesitan, por ende, tres llaves para abrirla e ingresar a ella.

¿Cuántos incumplimientos debe probar ahora la entidad vigilada para quedar exonerada?

Otro ejemplo. Además de la clave y el token, una entidad vigilada puede considerar, voluntariamente, proveer a sus clientes un software que ayude a prevenir (no corregir) que el equipo que está utilizando se conecte a un sitio falso en donde se le capturan los datos al cliente ("pharming"). Normalmente, las entidades financieras indican que este software es una "ayuda"; a su vez, quienes proveen estos softwares indican que detectan pero no eliminan amenazas ${ }^{52}$ pues no son un antivirus (cuya obligación de tenerlo y de tenerlo actualizado es del cliente). Estos softwares se enfocan en prevenir el fraude que ocurre desde la perspectiva de la entidad financiera, no desde la perspectiva del cliente.

En síntesis: las mayores seguridades que intente proveer una entidad vigilada a sus clientes terminan jugando en su contra en caso de fraude bancario. Así las cosas, hay un desincentivo a la entidad vigilada para proveer mayor seguridad a sus clientes por encima de las exigencias legales, más aún si esas mayores seguridades pueden afectar la "experiencia del usuario" al usar el portal virtual, pues “[...] cualquier proceso de seguridad explícito va a requerir de un determinado grado de 'molestia' al usuario. La determinación del balance entre molestia y usabilidad es lo que va a marcar la diferencia para nuestros usuarios" 53 . newweb/images/stories/downloads/DSB_FAQs.pdf.

53 Fabio Devin, "Seguridad en experiencia del usuario: tipos de seguridad", UXpañol. Discusiones sobre experiencia de usuario, acceso el 3 de junio de 2020, https://uxpanol.com/interaccion-de-usuarios/ seguridad-en-experiencia-de-usuario-tipos-de-seguridad/. 
Un comentario adicional: el mecanismo de doble autenticación que se establece con el banco para acceder a su portal virtual, compuesto por clave y token, es una firma electrónica pues permite identificar al cliente y es confiable, en los términos de la Ley 527 de $1999^{[54]}$ en su artículo 7. ${ }^{\circ}$ y el Decreto 2364 de 2012 ${ }^{[55]}$, incorporado en los artículos 2.2.2.47.1 y siguientes del Decreto 1074 de 2015 ${ }^{[56]}$. Por tanto, si alguien se identificó con las claves para ingresar al portal virtual pero, además, cada vez que el portal virtual le requirió la clave otra vez para confirmar una operación que se pretendía hacer en él, esa confirmación fue firmada electrónicamente.

Indiscutiblemente nada es infalible, y no sería por tanto un imposible que alguien con ganas de robar dinero, en vez de ir por el camino tortuoso y complicado de socavar a un cliente su clave y número de token a través de una invitación a un enlace para hacerse millonario o gracias a que el cliente compró en la esquina una USB con 500 canciones para la fiesta de fin de año, decidiera tomar por el camino "fácil y expedito" de conectar muchos computadores costosos y ponerlos a descifrar el algoritmo que tiene el banco o su proveedor de tokens para identificar la clave de cada usuario o el algoritmo que genera el número cambiante que arrojará un token.

Algo "fácil".

Pero en ese caso, de lograrlo, ¿será que quien hubiera logrado ello se dedicaría a robar cuentas de ahorros en cuantías de 300 millones o 1000 millones de pesos, o más bien contactaría al banco o a quien provee el token y les pediría una suma de dinero con unos ceros de más, y en divisas, para no revelar al mercado esa falencia?

En buena hora la SFC emitió la Circular Externa 007 del 5 de junio de 2018 sobre exigencias de ciberseguridad a las entidades vigiladas, la cual quedó incorporada en la parte 1 , título IV, capítulo $V$ de la CBJ. A partir de ella, las entidades vigiladas tienen obligaciones de reportar "ciberamenazas", de "reportar a los consumidores financieros, sobre incidentes cibernéticos que hubiesen afectado la confidencialidad o integridad de su información, así como las medidas adoptadas para remediar la información", y de "informar a los consumidores financieros de la entidad sobre las medidas de seguridad y recomendaciones que deberán adoptar para su ciberseguridad". Esto servirá para dar a conocer fallas en la seguridad de

54 Ley $527 / 1999$.

55 Decreto 2364/2012.

56 Decreto 1074/2015. 
los bancos en estos temas, de manera que facilite ubicar cuál eslabón de la cadena que existe entre un cliente y una entidad vigilada falló y a quien debe atribuírsele la causa del daño.

\section{Que la entidad vigilada sí cumplió con las obligaciones}

\section{a su cargo}

Como es apenas lógico, las entidades vigiladas tienen varias obligaciones. Nos centraremos en algunas que están en la Circular Básica Jurídica en su parte 1 (instrucciones generales aplicables a las entidades vigiladas), título II (prestación de los servicios financieros), capítulo 1 (canales, medios, seguridad y calidad en el manejo de información en la prestación de servicios financieros), numeral 2 (seguridad y calidad para la realización de operaciones), la cual fue actualizada con la Circular Externa 8 de 2018 (CE8).

Transcribimos las que consideramos más pertinentes para analizar un fraude electrónico a través del portal virtual de una entidad vigilada que es establecimiento de crédito accediendo a él por internet, dividiéndolas por grupos.

1. Un primer grupo se refiere a aquellas obligaciones en cuanto a la seguridad de la información y la de sus terminales, equipos y redes locales. Para el efecto, la CE8 en sus numerales 2.3.3.1 y siguientes establece que las entidades vigiladas deben aplicar un estándar ISO 27000 o el que lo sustituya (actualmente está vigente el ISO 27003) en cuanto a seguridad de la información, velar por que la información que remitan a sus clientes se haga en condiciones de seguridad y que sus terminales (las de la entidad vigilada), sus equipos internos y redes locales tengan los elementos necesarios para evitar la instalación de programas o dispositivos que capturen la información de sus clientes y de sus operaciones. Igualmente, según se indica en el numeral 2.3.3.1.9 de este capítulo, ofrecer a los clientes los mecanismos para que estos puedan personalizar las condiciones de manejo para la realización de operaciones, tales como inscribir direcciones IP o inscribir cuentas bancarias de destino.

La personalización se traduce en la práctica en que el cliente que es una persona jurídica puede definir cuáles de los siete días de la semana pueden hacerse transferencias a través del portal virtual, hasta qué monto diario permite hacerlas, si se necesita de un token y una clave personal asignados a una persona para "cargar" una transacción y además de otro token y otra clave personal asignados a 
otra persona para "ejecutarla", etc. La configuración por defecto apenas se entra a un portal virtual parte de no tener marcado ningún día de la semana ni ningún rango de montos. Es el cliente quien, administrando ese portal, decide marcar si quiere tener la posibilidad de entrar todos los días de la semana o solo entre semana, los montos límites, o activar otras restricciones que considere oportunas según el caso.

Sin embargo, la norma de la SFC solo se enfoca en que las entidades vigiladas ofrezcan.

En el terreno jurisprudencial la Corte Suprema de Justicia, en la sentencia de casación del 19 de diciembre de 2016 ya comentada, manifestó los efectos en cuanto a si un cliente, teniendo posibilidad de usar estos mecanismos para parametrizar, no los utiliza:

Tampoco se desvirtúa con la ausencia de restricciones informadas por la gestora, diferentes al monto de las operaciones diarias, puesto que la inexistencia de las mismas no disminuye el grado de responsabilidad del establecimiento bancario. Si bien el cliente tiene la facultad de fijar patrones en el manejo de sus cuentas que deben respetarse, quien en últimas debe tomar todas las precauciones para evitar sustracciones indebidas es el banco por ser el guardián de los dineros, debiendo asumir las pérdidas si el comportamiento del titular o sus autorizados estuvo acorde con las directrices impartidas ${ }^{57}$.

Ahora hilemos esta aseveración de la Corte Suprema con el estándar de comportamiento que se espera de los comerciantes basado en el "buen hombre de negocios" de la Ley 222 que tratamos anteriormente y que se basa en tener un comportamiento "prudente y diligente", que es exigible a una persona jurídica del tipo sociedad anónima como comerciante que es.

Y entonces nos preguntamos ¿no sería más bien que si un comerciante, como lo es una sociedad anónima, que fuera cliente de una entidad vigilada y que dispone a través de un portal transaccional de los dineros que tiene depositados, en desarrollo de sus deberes de prudencia ${ }^{58}$ y diligencia ${ }^{59}$ propios de un "buen hombre de negocios", debería parametrizar o personalizar acorde con sus necesidades la manera en que hará uso del portal transaccional si esa entidad vigilada le hubiere facilitado los mecanismos para hacerlo?

Corte Suprema de Justicia, Sala de Casación Civil, sentencia del 19 de diciembre de 2016. 
Un segundo grupo es el referente a la documentación de las transacciones hechas por los clientes, al respecto, la CE8 en su numeral 2.3.3.2.1 indica que la entidad vigilada debe "Dejar constancia de todas las operaciones que se realicen a través de los distintos canales, la cual debe contener cuando menos lo siguiente: fecha, hora, código del dispositivo (para operaciones realizadas a través de IVR: el número del teléfono desde el cual se hizo la llamada; para operaciones por Internet: la dirección IP desde la cual se hizo la misma; para operaciones con dispositivos móviles, el número desde el cual se hizo la conexión), cuenta(s), número de la operación y costo de la misma para el cliente o usuario".

Esto es lo que se denomina el "log transaccional".

En informática, se usa el término $\log$, historial de $\log$ o registro a la grabación secuencial en un archivo o en una base de datos de todos los acontecimientos (eventos o acciones) que afectan a un proceso particular (aplicación, actividad de una red informática, etc.). De esta forma constituye una evidencia del comportamiento del sistema.

Por derivación, el proceso de generación del log se le suele llamar guardar, registrar o loguear (un neologismo del inglés logging) y al proceso o sistema que realiza la grabación en el log se le suele llamar logger o registrador.

Generalmente los acontecimientos vienen anotados con:

- El momento exacto o data (fecha, hora, minuto, segundo) en el que ocurrió lo que permite analizar paso a paso la actividad.

- Una o más categorizaciones del acontecimiento registrado. Es frecuente usar categorías distintas para distinguir la importancia del acontecimiento estableciendo distintos niveles de registro los cuales suelen ser: depuración, información, advertencia y error ${ }^{60}$.

\section{A) El perfil transaccional}

1. Es el tercer grupo de obligaciones, y por ser tan interesantes, merecen una revisión más detallada.

La Circular Básica Jurídica (CBJ) en su parte 1, título 2, capítulo 1 (correspondiente a canales, medios, seguridad y calidad en el manejo de información en la prestación de servicios financieros, la cual incorporó la CE8 ya comentada), dispone que las entidades vigiladas deben adoptar al menos las siguientes medidas en materia de seguridad y calidad de la información: 
2.3.3.1.12. Establecer procedimientos para el bloqueo de canales o de instrumentos para la realización de operaciones, cuando existan situaciones o hechos que lo ameriten o después de un número de intentos de accesos fallidos por parte de un cliente, así como las medidas operativas y de seguridad para la reactivación de los mismos.

2.3.3.1.13. Elaborar el perfil de las costumbres transaccionales de cada uno de sus clientes y definir procedimientos para la confirmación oportuna de las operaciones monetarias que no correspondan a sus hábitos.

Lo primero es tener claro cuáles son los verbos rectores de las medidas que deben adoptar las entidades vigiladas: establecer procedimientos de bloqueo, elaborar el perfil de las costumbres transaccionales y definir procedimientos para la confirmación.

Por tanto, si el banco establece esos procedimientos, elabora esos perfiles y define los procedimientos para la confirmación de las operaciones monetarias que no correspondan a sus hábitos, se supone que cumple con la norma.

2. En el caso de la primera medida, se indica que el procedimiento de bloqueo de un canal (el portal virtual, en este caso) puede derivarse de dos situaciones: (1) cuando existan situaciones o hechos que lo ameriten por una parte o (2) después de un número de intentos fallidos por parte del cliente.

Para este documento es interesante revisar la primera, puesto que los hechos o situaciones que "lo ameritan" no están definidos por la SFC sino que lo deja a juicio de las entidades vigiladas. Pero lo más importante es que la aplicación del procedimiento y la decisión de bloquear están intrínsecamente relacionadas con la siguiente obligación: la de elaborar el perfil de las costumbres transaccionales de cada uno de sus clientes.

Es este criterio el que da la mayor cantidad de herramientas a las entidades vigiladas para saber si hay "situaciones o hechos que lo ameriten [...]".

3. Una primera lectura parecería llevar a la conclusión de que se mezclan dos conceptos distintos: una cosa es el perfil ${ }^{61}$ de una persona y otra cosa son sus hábitos $^{62}$ o costumbres ${ }^{63}$. A manera de analogía: un hombre, soltero y cuarentón, puede comprar un carro deportivo, y por su perfil, podríamos inferir que lo va a manejar a muy altas velocidades. Cosa distinta es que su costumbre sea manejarlo siempre a 50 kilómetros por hora.

61 "Perfil: Conjunto de rasgos peculiares que caracterizan a alguien o algo." Rae.es.

62 "Hábito: Modo especial de proceder o conducirse adquirido por repetición de actos iguales o semejantes, u originado por tendencias instintivas." Rae.es.

63 "Costumbre: Manera habitual de actuar o comportarse." Rae.es. 
Dicho lo anterior, la norma basa la elaboración en los clientes, no en los productos. A nuestro juicio, la norma no busca que se construya el perfil únicamente basado en la utilización previa de un producto determinado que tiene contratado con la entidad vigilada (de por sí, esto sería ilógico en el caso de un cliente nuevo que contrata un producto por primera vez con una entidad, pues no hay costumbres transaccionales previas con base en qué elaborar) sino contra el comportamiento transaccional de ese cliente, teniendo en cuenta quién es y respecto de, no solo ese producto, sino de otros productos financieros con esa y otras entidades vigiladas, e incluso con su comportamiento transaccional en el sector real.

Lo anterior obedece a algo obvio: Cuanta más información se tenga para elaborar un perfil transaccional, más criterios se tendrán para sustentar o no la decisión de aplicar un bloqueo a una transacción por no ajustarse a aquél.

Sin embargo, en asuntos de protección al consumidor financiero no hay una definición de la SFC de lo que se entiende por "costumbres transaccionales" de un cliente para saber cómo armar el perfil de ellas. Si asimilamos eso a lo que se entiende por el "comportamiento del consumidor", entonces serían "el conjunto de actividades que realizan las personas cuando seleccionan, compran, evalúan y utilizan bienes y servicios, con el objeto de satisfacer sus deseos y necesidades, actividades en las que están implicados procesos mentales y emocionales, así como acciones físicas"64.

Sin embargo, la noción del sector real está enfocada en la compra de servicios, y con una finalidad que tal vez se enmarca en el campo aspiracional, propio de las tendencias consumistas del siglo XXI.

Así mismo, no hay una definición en las normas de protección al consumidor financiero establecidas en la CBJ y contenidas en la parte I, título III, capítulos I y II.

En donde sí se han desarrollado definiciones de perfil transaccional es en materia de prevención del lavado de activos y la financiación al terrorismo. A manera de ejemplo, citamos tres proveídas por expertos en la materia, sin perjuicio de invitar al lector a profundizar en el artículo de Alejandro Lozano Vila que se cita parcialmente en la última de ellas:

Un perfil es el conjunto de cualidades, capacidades, atributos y rasgos que definen las particularidades de un individuo o una empresa para tener un modelo o patrón de su comportamiento actual o futuro. A través del levantamiento del perfil de sus clientes una organización puede evaluar y tomar decisiones sobre cómo 
desarrollar su relación negocios. [...]. El perfil financiero es el conjunto de atributos y características socioeconómicas y financieras del cliente, ya sea un individuo o una empresa. Con el levantamiento del perfil financiero se busca definir un patrón o modelo de las capacidades financieras del cliente en términos del monto de sus ingresos y de su patrimonio, de las actividades económicas o comerciales que desarrolla para generar sus ingresos y construir su patrimonio, la ubicación geográfica en donde se desarrollan dichas actividades, el nivel de gastos y egresos, los financiamientos recibidos, entre otros atributos de orden financiero. [...]. Adicionalmente, se requiere levantar el perfil transaccional de los clientes que corresponde a la proyección del monto, frecuencia y tipo de operaciones que estiman realizarán con la organización como parte de la relación de negocios. El contraste y comparativo del perfil financiero y el perfil transaccional permite determinar la viabilidad de dicha proyección monto y frecuencia de operaciones considerando las características socioeconómicas y financieras del cliente ${ }^{65}$.

Es importante conocer los hábitos financieros de cada cliente, saber cuáles canales y lugares usan para retirar dinero, cuáles son los montos y días de retiro para analizar si estas actividades corresponden, o no, al perfil del consumidor. Si se salen de los parámetros normales, se analizan para determinar si son sospechosas y ponerlas en conocimiento de las autoridades. Para conocer el perfil transaccional, los bancos agrupan a sus clientes, es decir los segmentan, por ejemplo, según su profesión, estrato e ingresos, recopilan información de ellos y sus movimientos financieros, que acompañan las características de sus transacciones $y$, de acuerdo, a lo que se espera de cada uno de los grupos que se comportan de forma similar, se comparan las transacciones reales con las normales, según la capacidad económica ${ }^{66}$.

Perfil: Según el diccionario de la Real Academia Española, es un conjunto de rasgos peculiares que caracterizan a alguien o algo. Existen diferentes tipos de perfiles: socioeconómico, demográfico, financiero, transaccional, de crédito, etc. Como se verá en este texto, la idea es definir el perfil transaccional de una persona con base en su información de conocimiento del cliente (demográfica y socioeconómica) y de ahí deducir su perfil transaccional. Por lo tanto, cuando se haga referencia al perfil, se entiende que es una dupla de perfil del cliente y perfil transaccional asignado.

“Perfil financiero y perfil”, Central CRM, acceso el 29 de octubre de 2019, https://blog.central-crm. com/2019/04/perfil-financiero-y-perfil.html.

66 "El perfil transaccional: el reto del sector financiero", Riesgo cero, acceso el 29 de octubre de 2019, https://www.riesgoscero.com/blog/el-perfil-transaccional-el-reto-del-sector-financiero. 
[...] El poder de los perfiles en la detección del lavado de activos reside en el beneficio práctico de comparar las operaciones realizadas por el cliente con una serie de reglas descriptivas que conforman el perfil. De esta forma, la detección de operaciones inusuales no consiste en comparar lo que el cliente hace con todo lo que se sabe del cliente (formatos, documentos soporte, contratos, entrevistas, etc.), sino en realizar una serie de operaciones lógicas y matemáticas para verificar que las operaciones del cliente están dentro de su perfil. [...] Para que esto funcione, se deben sintetizar las características de cada cliente. Dado que varios clientes pueden compartir un perfil, se pueden agrupar en lo que comúnmente se denomina segmento de clientes, es decir, un grupo de clientes que se deben comportar en forma similar. En términos sencillos, cada cliente de la entidad financiera tiene asignado un perfil, este describe lo que se espera que sea su transaccionalidad, expresado en términos objetivos, empleando variables como tipo de transacción, monto, frecuencia, ubicación, canal, volatilidad y crecimiento. El perfil puede comprender operaciones individuales o consolidadas en diferentes periodos. [...] El perfilamiento de los clientes es una técnica ampliamente utilizada en el sistema financiero para detectar lavado de activos y financiación del terrorismo. El reto consiste en emplear herramientas estadísticas predictivas que permitan asignarle a cada grupo de clientes un perfil de su frecuencia y capacidad de transacción usual. Existen varias disciplinas y campos en los cuales se trabaja con el concepto de perfiles [...]. Del sinnúmero de técnicas disponibles sobresalen los árboles de clasificación; pues permiten trabajar en forma independiente las variables de conocimiento del cliente (demográficas y socioeconómicas) y las transaccionales. De esta forma, es posible predecir la frecuencia y capacidad de transacción de un cliente basado en datos verificables o fáciles de obtener ${ }^{67}$.

Cuando se leen estas definiciones, de distintas fuentes, en donde se reconocen elementos del uso del producto y del cliente en sí, y elementos del comportamiento pasado para aceptar posibles comportamientos futuros que no sean idénticos a aquellos, queda claro por qué la obligación que establece la SFC en la CBJ en el capítulo referente a "Canales, medios, seguridad y calidad en el manejo de información en la prestación de servicios financieros" a las entidades vigiladas es la de establecer procedimientos de bloqueo, elaborar el perfil de las costumbres transaccionales y definir procedimientos para la confirmación de las operaciones, y no sencillamente una obligación de "bloquear las operaciones que no se ajustaren al perfil transaccional". 


\section{B) Entonces, a falta de una definición normativa en materia de protección al consumidor financiero, ¿qué es el perfil de las costumbres transaccionales?}

1. A falta de definición legal nos remitimos a la jurisprudencia, la cual ahonda más y más en el subjetivismo del juez.

El Tribunal Superior de Bogotá (Sala de Decisión Civil), en fallo del 27 de octubre de 2017, MP: Valenzuela Valbuena (1100131990012015-206-01), en el que revocó parcialmente una sentencia de la Delegatura para Funciones Jurisdiccionales de la SFC en la que esta había exonerado a la entidad bancaria al considerar, como parte de sus argumentos, que las operaciones objetadas sí se habían ajustado al perfil transaccional, indicó lo siguiente al referirse al "perfil transaccional", extracto que a su vez es publicado por la SFC en su página virtual en su "Reseña de jurisprudencia" ${ }^{68}$ sobre el consumidor financiero:

Porque el perfil transaccional no es una noción puramente formal, una especie de conocimiento que no requiere ningún tipo de investigación -apriorístico- sino que es el resultado del análisis de experiencias a cuya reiteración en el tiempo el ordenamiento quiso darle efectos propios. Así en línea de principio, el titular de un producto bancario no asume pérdidas por las operaciones que no ha realizado, incluso cuando culposamente ha facilitado a terceros las realicen, cuando las mismas se separen de sus costumbres transaccionales.

Podría decirse, con recurso a la figura, que el perfil transaccional es a las operaciones bancarias lo que la huella dactilar es a cada individuo; es aquel aspecto cuya singularidad ${ }^{69}$ permite establecer -por encima de la apariencia que se produce en los eventos en los que terceros superan o se hacen a los mecanismos tradicionales de autenticación (firma, clave personal, token, etc.)- la identidad de quien realiza una operación que prima facie podría imputarse al cliente.

De esta primera afirmación se concluye que el Tribunal define el perfil transaccional como algo basado en un comportamiento pasado, y en la identidad ("huella dactilar") de un comportamiento futuro que es comparado con aquel. Por ejemplo, si una transacción excede en su monto, así sea en pequeño porcentaje, las que un cliente venía haciendo antes, ella no correspondería al perfil transaccional.

A diferencia de las definiciones de perfil, hábito y costumbres dadas por la Real Academia, esta definición no parte de la base de que con la información que

"Reseña de jurisprudencia", Superintendencia Financiera de Colombia, acceso el 28 de septiembre de 2019, https://www.superfinanciera.gov.co/inicio/10087981. 
se tiene de un cliente se puede inferir qué operaciones futuras son atribuibles a él, así estas no sean idénticas a las hechas antes.

Posteriormente el Tribunal indica:

Para que un banco no sea responsable debe demostrar que hubo culpa de la víctima al haber permitido que terceros tuvieran acceso a la información necesaria para la realización de operaciones; pero, además, (el banco debe) acreditar que dichas operaciones se adecuaban a los hábitos transaccionales del cliente, esto es, y sin pretensiones de exhaustividad: que se hicieron en los días que suele transar, a través de la dirección IP normalmente utilizada -cuando de transacciones por internet se trata-, dentro de unas horas más o menos establecidas, en frecuencias que se vuelven asimismo determinables y por unos montos máximos o mínimos que se vuelven de cierto modo usuales, sin perder de vista la naturaleza misma de la transacción que se realiza: retiro de dineros en efectivo, transferencias o pagos, y tratándose de estos últimos, de qué tipos: de servicios públicos, privados, impuestos, etc. ${ }^{70}$.

Ya en este párrafo, a nuestro juicio el Tribunal parece confundir el perfil transaccional de un cliente con los hábitos de manejo que este tenga de un producto en concreto, desconociendo, a manera de ejemplo, la calidad del cliente en sí y la información que pueda tomar la entidad vigilada para la construcción de ese perfil derivada del manejo de otros productos financieros que tenga contratado ese cliente con ella o con otras entidades vigiladas o incluso el comportamiento financiero de ese cliente con el sector real.

Pero, más que eso, el Tribunal acá parece indicar en qué parámetros, a su juicio, debe darse la "identidad" para que una operación se considere ajustada a los hábitos transaccionales.

La duda que surge es si a juicio del Tribunal para que una transacción hecha por un portal virtual se entienda ajustada al perfil transaccional (y por ende no habría obligación de la entidad vigilada de bloquearla mientras la confirma) debe cumplir con todos y cada uno de los parámetros que él dice (días, dirección IP, horas, frecuencias, montos) o si basta con algunos, o si hay, como es obvio, otros que no están incluidos en esta definición pero que están basados precisamente en el cliente como persona natural o jurídica que es, como, por ejemplo, edad, sexo, estrato, segmento de negocio, actividad empresarial, ocupación, ubicación, patrimonio, existencia o no de otros productos financieros distintos de los depósitos 
de ahorros y uso de estos, si está casado, si tiene vivienda propia, si tiene hijos, si tiene filiales, si tiene mascota, si tiene carro, etc. Situaciones y comportamientos que también son parte de la "identidad" de las personas o de su pasado y que indefectiblemente deben tenerse en cuenta a la hora de inferir el manejo futuro de sus productos financieros.

Por ejemplo, supongamos que Vigicol, empresa de vigilancia con más de 300 empleados, tiene activados los siete días de la semana para hacer transferencias de recursos y hasta por 1000 millones de pesos mensuales como suma total desde tres cuentas bancarias que tiene. Los "hábitos" de la empresa nos indican que desde la cuenta A hace transferencias y pagos por PSE ${ }^{71}$ los lunes y miércoles hasta por 500 millones diarios, desde la cuenta B hace transferencias y pagos por PSE los jueves y viernes hasta por 60 millones diarios, y desde la cuenta $C$ hace transferencias los lunes y viernes hasta por 30 millones diarios pero no hace pagos por PSE. Se presenta una transferencia desde la cuenta C un martes por una cuantía de 100 millones de pesos y un pago PSE por 70 millones. La IP desde donde se hace es la usual. Estas dos transferencias se objetan.

¿Estas dos transacciones se ajustan al perfil de las costumbres transaccionales de Vigicol, como pretende la norma? O más bien debemos preguntarnos si esas dos transacciones se ajustan al manejo transaccional de la cuenta $C$, como lo pretende el Tribunal.

Más adelante el Tribunal indica, en un párrafo que no reseña la SFC en su página virtual:

Al efecto, se echan de menos los promedios generales del tipo de operaciones que solía realizar el cliente, sus frecuencias, tipo, cantidades negociadas, etc.; o, y tal vez esta era la prueba que precisaban las defensas de Davivienda, que con anterioridad a las transacciones del 14 de septiembre de 2016 el cliente ya había realizado otras en condiciones cualitativa y cuantitativamente similares [énfasis nuestro].

Acá vemos cómo en la misma sentencia se pasa de un criterio de "identidad" a uno de "similitud". Sobra decir que no son lo mismo.

Pero surge entonces una duda aún más importante: ¿Cuándo, a ojos del Tribunal, algo empieza a tener condiciones cualitativas y cuantitativas "similares"?

71 PSE es un botón de pagos ofrecido por ACH Colombia S. A., una entidad vigilada que no es un establecimiento bancario. "Este servicio permite a las empresas ofrecer a sus clientes la posibilidad de realizar pagos y/o compras, debitando los recursos en línea de la Entidad Financiera donde el cliente tiene su dinero y depositándolos en la entidad financiera recaudadora que defina la Empresa o Comercio", "PSE: cómo funciona”, Pagos Seguros en Línea - PSE, acceso el 6 de agosto de 2019, https://www.pse.com.co/como-funciona. 
Para el efecto, valga traer a colación este último análisis del Tribunal, tampoco reproducido por la SFC en su página sobre "Reseñas jurisprudenciales":

Y ello es así porque aun cuando la utilización del portal en días no laborales comenzaba a ser indicativa de un hábito, la naturaleza bien caracterizada que se predica de la costumbre como elemento fundacional del perfil transaccional no queda fehacientemente acreditada con el sólo hecho de que el cliente acceda y realice operaciones en un momento dado, sino que está dada por las cualidades propias de las operaciones mismas, se insiste, por sus aspectos cuantitativos y cualitativos [énfasis nuestro].

¿Alguien podría decir cuándo algo empieza a ser "indicativo" de un "hábito", cuándo algo es un "hábito" y cuándo algo se torna en una "costumbre”? o ¿cuándo algo que era una costumbre deja de serlo?, ¿o si todo depende de cómo haya estado el día de quien o quienes estén redactando la sentencia?

En síntesis, y nos devolvemos a la analogía de la balanza con la que iniciaba la segunda parte de este artículo: al menos el 50\% de los factores que deciden la responsabilidad en los casos de protección al consumidor financiero están sometidos a un análisis altamente subjetivo del operador judicial de lo que a su juicio considere en cuanto a si una transacción se ajusta al perfil de las costumbres transaccionales de un cliente, pues no hay un criterio legal claro que le indique qué es un perfil transaccional y cuál es su diferencia con los hábitos transaccionales, cómo se construye y qué información se tiene en cuenta para considerar que algo es parte de las costumbres transaccionales de un cliente.

2. Vemos además cómo el Tribunal, siendo cuestionable si es la autoridad estatal Ilamada a hacerlo, ni siquiera lo había hecho la SFC, hizo dos cosas en este fallo:

(a) Definió el perfil transaccional de los consumidores financieros y los elementos que a su juicio conforman el mismo sin entender qué es y sin tener los conocimientos técnicos para ello.

(b) Estableció jurisprudencialmente una nueva obligación, y "de resultado", a cargo de las entidades vigiladas: estas deben bloquear una transacción si ella no se ajusta a lo que a juicio del Tribunal es el perfil de las costumbres transaccionales.

Ya no importa si cumplieron las obligaciones de la CBJ de elaborar el perfil de las costumbres transaccionales, de establecer procedimientos de bloqueo y cumplirlos, y de definir procedimientos para la confirmación. 
Pero, sobre todo, ya no importa si cuando la entidad vigilada elaboró su procedimiento de bloqueo, cuando construyó su algoritmo para definir qué operaciones se considerarían "costumbres transaccionales" para armar el perfil de sus clientes o cuando estableció el procedimiento de confirmación, todo esto fue revisado en un momento anterior por la SFC en ejercicio de sus funciones administrativas (no jurisdiccionales) que tiene establecidas en el artículo 11.2.1.4.21 del DU, y esta no presentó objeciones ni solicitó hacer ajustes a ese procedimiento bloqueo, ese algoritmo o ese procedimiento de confirmación.

Valga recordar que el artículo 78 de la Constitución Política estableció un rango constitucional a la protección al consumidor financiero en donde las entidades vigiladas son quienes proveen estos servicios, y estableció que ellas serán responsables, según se establezca en la ley, al indicar que "Serán responsables, de acuerdo con la ley, quienes en la producción y en la comercialización de bienes y servicios, atenten contra la salud, la seguridad y el adecuado aprovisionamiento a consumidores y usuarios. [...]".

También estas tienen, entonces, en el ámbito constitucional, la definición de cómo se establece su responsabilidad en esta materia.

3. ¿Cómo se podría dar una certeza jurídica a esto? Consideramos que con una definición establecida por la SFC de lo que entiende por las costumbres transaccionales y de qué información se toma para concluir que una o varias transacciones hacen parte de aquellas para así poder elaborar el perfil de aquellas. Dicha definición debería ser clara en referirse a que ese perfil se construye no solo a partir de la información del manejo pasado de ese producto, sino teniendo en cuenta el manejo de otros productos (lo que hace) y sobre todo las particularidades del cliente en sí (lo que es).

¿O podemos concluir que ya lo hizo cuando decidió incluir en su página virtual a manera de "reseña jurisprudencial" la noción de "huella dactilar" que dio el Tribunal?

Lo bueno de establecer algo con base en criterios más claros es que las plataformas tecnológicas que sirven para soportar los portales virtuales de las entidades vigiladas se podrían parametrizar con ellos de una manera automática, sin perjuicio de que la entidad vigilada bloqueara los canales a partir de otros criterios adicionales, si considera que una transacción no se ajusta al perfil de las costumbres transaccionales del cliente.

Esto ayudaría bastante a prevenir los fraudes a través de internet y a disminuir las situaciones litigiosas. Basta indicar que en 2018, 892.212 (66\%) de las 1.348.007 quejas del sector estuvieron relacionadas con establecimientos 
bancarios. De esas 892.212 quejas, 261.412 estuvieron relacionadas con cuentas de ahorro o corrientes.

$Y$ de esas 261.412 quejas, 86.804 quejas fueron derivadas de indebida atención al consumidor financiero-servicio, aspectos contractuales (incumplimiento o modificación), descuentos injustificados, suplantación presunta de persona, fallas en internet y bloqueo (productos). Es decir, el 6,4\% del total de quejas del sector ${ }^{72}$.

\section{C) Las "nuevas obligaciones" establecidas por la Corte Suprema de Justicia}

En su sentencia del 19 de diciembre de 2016 ya citada, la Corte Suprema de Justicia parece establecer, o al menos sugerir, las que parecen ser unas nuevas obligaciones a las entidades vigiladas sin que hayan sido establecidas por la ley o por la SFC.

El bloqueo, no solo de las cuentas bancarias desde donde salen los recursos sino también el de las cuentas que los reciben

En suma, los bancos al ofrecer a sus clientes la prestación de servicios bancarios a través de un portal de internet, las medidas de precaución y diligencia que le son exigibles no corresponden a las mínimas requeridas en cualquier actividad comercial, sino a aquellas de alto nivel que puedan garantizar la realización de las transacciones electrónicas de forma segura, siendo requerida la implementación de herramientas, instrumentos o mecanismos tecnológicos adecuados, idóneos y suficientes para evitar la contingencia de la defraudación por medios virtuales o minimizar al máximo su ocurrencia, rodeando de la debida seguridad el entorno web en que se desarrolla, los elementos empleados, las contraseñas y claves, el acceso al sistema, la autenticación de los usuarios, la trazabilidad de las transacciones, el sistema de alertas por movimientos sospechosos o ajenos al perfil transaccional del cliente y el bloqueo de cuentas destinatarias en transferencias irregulares, de ser el $\mathrm{caso}^{73}$.

En síntesis, la CSJ establece los primeros basamentos del análisis del perfil de las costumbres transaccionales de los clientes de los otros bancos que reciben los recursos. Así las cosas, se podría pensar que un banco podría llamar en garantía a otro si considera que este debió haber bloqueado las cuentas destinatarias abiertas en este último si la entrada de dineros no se ajustaba a ese perfil transaccional. 
El establecimiento por las entidades vigiladas de canales de información seguros a través de VPN para el viaje la información que los clientes remiten o reciben de aquellas

De la exposición que precede, queda claro que en el caso de defraudación por transacciones electrónicas, dado que tal contingencia o riesgo es inherente a la actividad bancaria la cual es profesional, habitual y lucrativa, cuya realización requiere de altos estándares de diligencia, seguridad, control, confiabilidad y profesionalismo, que también tienen que ser atendidos en materia de seguridad de la información que sea transmitida por esa vía, siendo innegable e ineludible su obligación de garantizar la seguridad de las transacciones que autoriza por cualquiera de los medios ofrecidos al público y con independencia de si los dineros sustraídos provienen de cuentas de ahorro o de cuentas corrientes ${ }^{74}$.

Acá, al parecer, la Corte parece sugerir que las entidades vigiladas son responsables no solo porque sus portales virtuales no sean vulnerados sino también por la transmisión segura de los datos desde los computadores de los clientes hacia ellos, y viceversa. Haciendo la analogía, las entidades vigiladas tendrían que responder no solo por la seguridad de la oficina ubicada en un barrio de una ciudad sino también por la seguridad de las calles que llevan a esa oficina. Eso se logra en parte con una "red virtual privada" o VPN (virtual private network).

Una VPN es una tecnología de red que se utiliza para conectar una o más computadoras a una red privada utilizando internet. Las empresas suelen utilizar estas redes para que sus empleados, desde sus casas, hoteles, etc., puedan acceder a recursos corporativos que de otro modo no tendrían a disposición ${ }^{75}$. Para su funcionamiento y finalidades, sugerimos acceder a un video explicativo en internet ${ }^{76}$.

Es más, en el mismo fallo se encuentra que una conclusión en ese sentido, de uno de los peritos del caso, fue altamente compartida por la Corte. Ella incluso se dio a la tarea de transcribirla en el fallo ${ }^{77}$ :

Pregunta: Díganos si el Banco Comercial AV Villas S. A. pudo haber tomado medidas para evitar que el funcionario de Tax Individual S. A. al intentar ingresar a su

Ibíd., 56.

“Qué es y cómo funciona una VPN?", Welivesecurity, acceso el 31 de agosto de 2019, https://www. welivesecurity.com/la-es/2012/09/10/vpn-funcionamiento-privacidad-informacion/.

"What is a VPN and how does it work?" YouTube, acceso el 28 de septiembre de 2019, https://www. youtube.com/channel/UCEA9ROzwUTy6t-QdLuWrjnw.

Corte Suprema de Justicia, sentencia del 19 de diciembre de 2016, 68. 
página no fuera desviado a un protocolo no seguro como aconteció en este caso. Respuesta: Sí, a través de medidas de seguridad como una VPN.

Como lo indican quienes han analizado el alcance de la potencial exigencia de la VPN a raíz de esta sentencia, "la conclusión del caso en particular fue que el banco debió haber extremado sus medidas de seguridad para hacer la comunicación de sus clientes más confiables, pero también debemos anotar que en esta situación nunca se accedió a los sistemas del banco y estos no estuvieron en peligro"78.

Sin embargo, vale la pena indicar dos cosas:

- No hay una obligación concreta, legal o establecida por la SFC, de que los bancos deban establecer VPN a sus clientes para el acceso a los portales virtuales.

- La posibilidad de un servicio mensual de una VPN no es algo restrictivo de los bancos sino que es algo a lo que puede acceder cualquier persona jurídica en el mercado ${ }^{79}$ a unos costos similares o inferiores ${ }^{80}$ a los de un entretenimiento como lo es la televisión por streaming (Netflix). Entonces, ¿por qué esta obligación la CSJ solo la sugiere para uno de los extremos de la relación y no en cabeza del otro, cuando de este otro se espera que sea un buen hombre de negocios, y más aún cuando los usos de la VPN no se cierran a la encriptación de datos para temas bancarios sino también para mantener el anonimato, superar censuras en internet, proteger sus datos en general o para transmitir en general datos a clientes y proveedores de manera segura?

De por sí, hay casos en que los expertos en seguridad informática -es decir personas o compañías que también podrían ser peritos- sugieren no contratar una VPN:

Hidemyass es un portal de internet que ofrece la contratación de VPN. Es además parte de Avast $^{81}$, una empresa internacional dedicada a la seguridad en

Ustáriz, Responsabilidad bancaria por fraude electrónico.

79 "Mejores VPN de 2019", TOP1OVPN, acceso el 28 de septiembre de 2019, https://www.top10vpn. $\mathrm{com} /$ mejores-vpn/?bsid=c47se1kw275\&gclid=EAlalQobChMI6vqVu8Ps5AIVBYeGCh346gcDEAA YASAAEgKrgfD_BwE.

80 Un servicio contratado por tres años cuesta en Cyberghost USD 2,75 por mes, Cyber Ghost, acceso el 4 de junio de 2019, https://www.cyberghostvpn.com/es_ES/buy/cyberghost-vpn-4.

81 "Conozca hydemyass", HMA, acceso el 28 de septiembre de 2019, https://www.hidemyass.com/ es-es/about-us. 
línea ${ }^{82}$. En el primero de esos portales se establece una buena explicación de para qué sirve y para qué no sirve una VPN ${ }^{83}$.

Baste transcribir un comentario de esa página para invitar a su lectura:

Tu herramienta bancaria más segura: el sentido común

Vamos a plantear una situación, ¿te parece? En la vida real, eres un ciudadano responsable. Cierras las puertas, cierras con llave el cobertizo de tu bicicleta, cubres el terminal cuando estás haciendo un pago. Dios, es precioso ver lo concienciado que estás con la privacidad cuando se trata de la vida real, pero... luego te conectas $y$, ¿qué pasa? Te conviertes en un exhibicionista, mostrando lo que quieras hasta que no quede nada para la imaginación.

Así que, por supuesto, una VPN no será de mucha ayuda cuando uses la banca en línea. Sin embargo, la buena noticia es que todo cuanto necesitas para usar la banca en línea de forma segura es gratuito y fácil de hacer si no eres perezoso como yo.

Usa contraseñas seguras: prueba un generador de contraseñas o una frase como contraseña para garantizar su superseguridad, y utiliza contraseñas distintas para cada una de tus cuentas. Mantenlas tan seguras como tu propia vida.

Navega de forma segura: asegúrate de que el sitio virtual que estás visitando sea real (es decir, no sigas vínculos raros) y de que use una dirección HTTPS. De lo contrario, échalo como si te debiera dinero o te hubiera dicho que te quiere por error. Usa un antivirus: preferiblemente uno bueno, pero, oye, eres libre de cometer los errores que quieras.

Archivos adjuntos: como los caramelos, pueden ser más divertidos los de gente extraña, pero siempre son más peligrosos. Descarga solo el contenido en el que confíes y analízalo antes de abrirlo.

Vínculos: ¿PayPal realmente necesita que autentiques tus datos? Probablemente no, pero si quieres asegurarte, ve directamente al sitio; no uses ningún vínculo que te ofrezcan.

Ya sé que no es interesante ni divertido, pero, si en algún momento han echado mano a tu dinero, sabes que no hay nada peor que llamar a algún teléfono de ayuda costoso para informar de que te han robado los ahorros y ser transferido de persona en persona hasta perder la paciencia. ¿No es mejor ir sobre seguro? A menos que seas el aventurero más humilde del mundo, claro está. En ese caso,

Al parecer esta empresa hace buenos productos en seguridad. Según se indica en su página, su antivirus fue galardonado "Product of the Year de 2018" por AV-Comparatives, una organización independiente enfocada en testear software de seguridad informática. El reporte del estudio 2018, qué antivirus se revisaron y demás se encuentra en "Summary Report 2018", AV comparatives, acceso el 28 de septiembre de 2019, https://www.av-comparatives.org/tests/summary-report-2018/. 
sigue tu camino y disfruta del leve subidón de adrenalina que supone hacer clic en vínculos extraños.

Resumiendo

Mira, sería genial si pudiéramos vender la VPN como la panacea para todos los quebraderos de cabeza de la red. ¡Estoy seguro de que el equipo de HMA! también preferiría venderte este cuento. Pero, si vamos a tener una relación cliente-mascota positiva, debemos confiar el uno en el otro. Así que no puedo mentirte acerca de qué no puede hacer una VPN, y a cambio tú prometes no piratear mi software con una licencia ilegal y, quizás, dejar de beber leche de burra.

\section{La obligación de garantizar la realización de las transacciones y rodear de la debida seguridad el entorno virtual}

Cerramos este artículo con algo parecido a la "excepción genérica" en los procesos civiles. Como ya lo anotamos, la CSJ indicó:

En suma, los bancos al ofrecer a sus clientes la prestación de servicios bancarios a través de un portal de internet, las medidas de precaución y diligencia que le son exigibles no corresponden a las mínimas requeridas en cualquier actividad comercial, sino a aquellas de alto nivel que puedan garantizar la realización de las transacciones electrónicas de forma segura, siendo requerida la implementación de herramientas, instrumentos o mecanismos tecnológicos adecuados, idóneos y suficientes para evitar la contingencia de la defraudación por medios virtuales o minimizar al máximo su ocurrencia, rodeando de la debida seguridad el entorno web en que se desarrolla, los elementos empleados, las contraseñas y claves, el acceso al sistema, la autenticación de los usuarios, la trazabilidad de las transacciones, el sistema de alertas por movimientos sospechosos o ajenos al perfil transaccional del cliente y el bloqueo de cuentas destinatarias en transferencias irregulares, de ser el caso ${ }^{84}$.

Este párrafo genera algunas preguntas.

¿Al indicarse que los bancos tienen la obligación de "garantizar" la realización de las transacciones y de "rodear de la debida seguridad el entorno web", ello implica un régimen de responsabilidad objetiva o una obligación de resultado, que para algunos autores se asimilan ${ }^{85}$, o más bien, debemos decirlo, una obligación a 
cargo del banco pero imposible de cumplir si el mismo consumidor no atiende a su propia protección?

Los elementos para concluir una tendencia jurisprudencial en Colombia a establecer un régimen de responsabilidad objetiva en temas financieros no son extraños en la situación acá planteada y han sido manifestados por otros autores, para quienes "lo más llamativo es que tal expansión no se ha originado de una elaboración diáfana o clara en la que abiertamente se reconozca el abandono del dolo y de la culpa como criterios predominantes de imputación de responsabilidad" 86 .

En cambio, en otros países, de manera más abierta, se ha establecido ello, como es el caso de España, en donde en la Ley General para Defensa de los Consumidores y Usuarios ${ }^{87}$ se diferencia entre un régimen de responsabilidad basado en culpa con inversión de la carga de la prueba regulado en el artículo 147 y uno de responsabilidad objetiva para ciertos servicios, regulado en el artículo 148, aplicando este último cuando "por su propia naturaleza, o por estar así reglamentariamente establecido, incluyan necesariamente la garantía de niveles determinados de eficacia o seguridad, en condiciones objetivas de determinación, y supongan controles técnicos, profesionales o sistemáticos de calidad, hasta llegar en debidas condiciones al consumidor y usuario". En este caso, "el demandante no debe probar la culpa del prestador del servicio, pero tiene que probar los demás requisitos básicos de la responsabilidad que establece este artículo. Así, corresponde al perjudicado probar que el daño se produjo durante el uso del servicio, el daño y la relación de causalidad entre este y dicho uso del servicio" 88 .

Así mismo, si por obligación de resultado entendemos, como lo ha hecho la Corte en temas de responsabilidad médica, aquella en que "el interés primario del titular del derecho crediticio sí se puede obtener con el comportamiento o conducta debida, toda vez que en ellas la presencia del componente aleatorio o de azar es exigua, y por ende, el deudor sí puede garantizar que el acreedor obtenga el resultado o logro concreto que constituye dicho interés primario"89, estaríamos en presencia de una situación de "garantía" a juicio de la Corte, con los efectos que ello tiene. prudencial para la responsabilidad bancaria", Revista Internacional Foro de Derecho Mercantil, n. ${ }^{\circ} 60$ (2018): 43, http://www.dlapipermb.com/images/docs/SIN-DOLO-Y-SIN-CULPA---MARTINEZ-YROJAS.pdf. 2015, 631, http://hdl.handle.net/10803/328430. 
Es más: si es una obligación de resultado, ¿esas exigencias son demandables a los bancos sin importar si al otro lado de la relación tenemos a un consumidor financiero que sea un comerciante que incumple sus obligaciones de una manera negligente, por ejemplo su obligación de no dar su clave a terceros, de no entrar al banco a partir de invitaciones por correo electrónico, etc.?

Desde el punto de vista técnico preocupa el entendimiento de lo que es la seguridad en internet que tiene la Corte y su ausencia en el análisis del factor humano dentro de los consumidores financieros que son personas jurídicas. Como lo indica el experto en ciberseguridad Gene Spafford, conocido por el desarrollo de la defensa basada en "tecnología del engaño"90-91, a manera de analogía: "el único sistema verdaderamente seguro es aquel que se encuentra apagado, encerrado en una caja fuerte de titanio, enterrado en un bloque de hormigón, rodeado de gas nervioso y vigilado por guardias armados y muy bien pagados. Incluso entonces, yo no apostaría mi vida en ello"92. O como lo indica Bruce Schneider, criptógrafo experto en seguridad informática, "si piensas que la tecnología puede resolver tus problemas de seguridad, entonces no entiendes el problema y no entiendes la tecnología"93.

De por sí, ¿qué entiende la CSJ por "entorno web"?, ¿es la Surface web, la Deep web o la Dark web? ${ }^{94}$

¿La CSJ considera entonces que la normativa que ha sacado la SFC sobre seguridad de la información, con todo el conocimiento técnico de quien supervisa al sistema financiero, y que se supone los bancos deben cumplir, es y siempre será insuficiente? Es más: si la seguridad en el portal virtual de un banco es verificada por la SFC en una visita como autoridad administrativa que es y esta no hace glosas o recomendaciones concretas a la entidad basadas en un incumplimiento a la $\mathrm{CBJ}$ en lo que respeta al portal virtual por no encontrar falencias que impliquen una amenaza para la seguridad de los dineros de los consumidores financieros en cuanto al uso de ese canal, ¿el banco puede, de buena fe, suponer que su sistema sí cumple con lo que exige la CSJ como estándar en este párrafo? https://es.wikipedia.org/wiki/Tecnolog\%C3\%ADa_del_enga\%C3\%B1o.

91 "Deception technology, iniciando la ofensiva", IT Digital Security, acceso el 4 de junio de 2020, https://www.itdigitalsecurity.es/reportajes/2018/02/deception-technology-iniciando-la-ofensiva.

92 Gómez, Enciclopedia de la Seguridad Informática, 19.

93 lbíd., 78.

94 “Deep web: cinco datos que no conocías”, BBVA, acceso el 25 de septiembre de 2019, https://www. bbva.com/es/deep-web-cinco-datos-curiosos-que-no-conocias/. 
¿Los bancos deben presumir que los clientes no cuidarán sus claves, que accederán a sitios de dudosa reputación, que no tendrán actualizados sus antivirus -o que ni siquiera los tendrán-, y por ende, como profesionales, deben anticiparse estableciendo protecciones para estas situaciones en las distintas situaciones que la CSJ menciona?

\section{Algunas conclusiones}

Hemos hecho un análisis de algunos puntos de la responsabilidad bancaria en materia de fraude electrónico. Para ello, hemos preferido invitar al lector a responderse a sí mismo varias cuestiones, de manera que sean su lógica y su sentido común los que concluyan, más que la ley, los jueces o nosotros.

Ahora, si nos piden unas conclusiones, estas, humildemente, serían:

- Dentro de la noción de consumidor financiero se equipara, como si fueran iguales, a personas naturales y jurídicas con distintas calidades.

- Existen los elementos legales y jurisprudenciales para que los jueces establezcan pautas que permitan revisar el comportamiento de un consumidor financiero con lo que se le puede exigir teniendo en cuenta sus características particulares.

- Hay elementos para sustentar un desarrollo jurisprudencial de los estándares de responsabilidad aplicables a los consumidores financieros cuando estos son comerciantes.

- La inexistencia de una noción legal concreta de lo que son las costumbres transaccionales de los consumidores financieros y cómo se construye el perfil de ellas hace que al menos el 50\% del análisis de responsabilidad de los bancos en estos campos esté sometido a un alto juicio de subjetividad por parte de los jueces sobre lo que se ajusta o no a ese perfil.

- Al analizar el entendimiento de la parte tecnológica que tienen la Corte Suprema de Justicia o el Tribunal Superior de Bogotá, no la teoría jurídica, hay no solo una discusión jurídica sobre la responsabilidad objetiva sino una sobre si ese régimen de responsabilidad se sustenta en el incumplimiento de obligaciones de resultado de los bancos, quienes, como expertos bancarios y que se lucran, deben, al parecer, anticiparse 
a la negligencia de sus clientes; incluso cuando estos, se supone, deben comportarse como buenos hombres de negocios.

- La Corte Suprema de Justicia y el Tribunal Superior de Bogotá, en los fallos analizados, parecen establecer nuevas obligaciones a las entidades vigiladas, tales como asumir el costo de las VPN para los clientes o analizar las costumbres transaccionales de los destinatarios de dinero por vías electrónicas, sin tener un conocimiento técnico para ello y sin ser la autoridad dentro del Estado llamada a hacerlo.

Gracias por leer este artículo.

\section{Referencias}

Circular Básica Contable y Financiera. Superintendencia Financiera de Colombia. Superintendencia Financiera de Colombia, https://www.su perfinanciera.gov.co/inicio/circular-basica-contable-y-financiera-circu lar-externa--de---15466.

Circular Básica Jurídica. Superintendencia Financiera de Colombia, https://www.superfinanciera.gov.co/inicio/normativa/normativa-gene$\mathrm{ral} /$ circular-basica-juridica-ce----10083443.

Código Civil y Comercial de la República Argentina. http://www.saij.gob. ar/cdigo-civil-comercial-nacin-ministerio-justicia-derechos-humanosnacin-lb000066-2014-10/123456789-0abc-defg-g66-0000blsorbil.

Constitución Política de Colombia.

Congreso de la República de Colombia, Gaceta del Congreso n. ${ }^{\circ} 515$ del 17 de junio de 2009.

Congreso de la República de Colombia, Gaceta del Congreso n. ${ }^{\circ} 563$ del 10 de julio de 2009.

Congreso de la República de Colombia, Gaceta del Congreso n. ${ }^{\circ} 138$ del 11 de abril de 2008.

Congreso de la República de Colombia, Gaceta del Congreso n. ${ }^{\circ} 594$ del 13 de agosto de 2015.

Consejo de Estado de Colombia. Sala de lo Contencioso Administrativo, sección primera, expediente 11001 03-24-000-2001-00003-01(6744). Sentencia del 2 de octubre de 2003. CP: Manuel Santiago Urueta Ayola. 
Consejo de Estado de Colombia. Sala de lo Contencioso Administrativo, sección primera, expediente 11001-03-24-000-2004-00390-01. Sentencia del 17 de marzo de 2011. CP: Rafael Ostau de Lafont Pianeta.

Consejo Superior de la Judicatura de Colombia. Plan de formación de la rama judicial - sistema financiero y bursátil. Bogotá: Imprenta Nacional, 2019.

Corte Constitucional de Colombia. Sentencia C-037/96, MP: Vladimiro Naranjo.

Corte Constitucional de Colombia. Sentencia C-131/99, MP: Alejandro Martínez Caballero.

Corte Constitucional de Colombia. Sentencia de unificación SU-047/99, MP: Carlos Gaviria Díaz y Alejandro Martínez Caballero.

Corte Constitucional de Colombia. Sentencia C-123/06. MP: Clara Vargas Hernández.

Corte Constitucional de Colombia. Sentencia C-909/12. MP: Nilson Pinilla.

Corte Constitucional de Colombia. Sentencia C-081/14. MP: Nilson Pinilla.

Corte Suprema de Justicia de Colombia. Sala de Casación Civil, expediente SC 18614-2016, sentencia del 19 de diciembre de 2016. MP: Ariel Salazar Ramírez.

Corte Suprema de Justicia de Colombia. Sala de Casación Civil, expediente 05001-31-03-012-2006-00234-01. Sentencia del 24 de mayo de 2017, MP: Armando Tolosa Villabona.

Decreto 3466 de 1982, 3 de diciembre. Diario Oficial 36.143.

Decreto 1243 de 2013, 14 de junio. Diario Oficial 48.821.

Decreto 2364 de 2012, 22 de noviembre. Diario Oficial 48.622.

Decreto 1498 de 2013, 15 de julio. Diario Oficial 48.852.

Decreto 2555 de 2010, 15 de julio. Diario Oficial 47.771.

Decreto 1074 de 2015, 26 de mayo. Diario Oficial 49.523.

Decreto 1357 de 2018, 31 de julio. Diario Oficial 50.671.

Decreto 1984 de 2018, 30 de octubre. Diario Oficial 50.762.

Devin, Fabio. "Seguridad en experiencia de usuario: tipos de seguridad". UXpañol, 24 de mayo de 2017: https://uxpanol.com/interaccion-de-usua rios/seguridad-en-experiencia-de-usuario-tipos-de-seguridad/. 
Díaz-Granados Ortiz, Juan Manuel. El seguro de responsabilidad (Bogotá: Universidad del Rosario, 2012).

Goujon, André. "¿Qué es una VPN y cómo funciona para la privacidad de la información?" Welive 10 de septiembre de 2012: https://www.weli vesecurity.com/la-es/2012/09/10/vpn-funcionamiento-privacidad-in formacion/.

Krugman, Paul y Robin Wells. Introducción a la economía: microeconomía. Barcelona: Editorial Reverté, 2007.

Kubica, Maria Lubomira. El riesgo y la responsabilidad objetiva (tesis doctoral), Universidad de Girona, 2015: http://hdl.handle.net/10803/328430.

Ley 222 de 1995, 20 de diciembre. Diario Oficial 42.156.

Ley 527 de 1999, 18 de agosto. Diario Oficial 43.673.

Ley 905 de 2004, 2 de agosto. Diario Oficial 45.628.

Ley 1328 de 2009, 15 de julio. Diario Oficial 47.411.

Ley 1480 de 2011, 12 de octubre. Diario Oficial 48.220.

Ley 1564 de 2012, 12 de julio. Diario Oficial 48.489.

Lozano Vila, Alberto "El perfil financiero: una estrategia para detectar el lavado de activos". Revista Criminalidad 50, n. ${ }^{\circ} 2$ (2008): http:// www.scielo.org.co/scielo.php?script=sci_arttext\&pid=S1794-310820 08000200004.

Mailló Fernández, Juan Andrés. Seguridad digital e informática. Madrid: Ra-Ma, 2017.

Martínez Beltrán, Camilo y Sergio Rojas Quiñones. "Sin dolo y sin culpa: un nuevo paradigma jurisprudencial para la responsabilidad bancaria". Revista Internacional Foro de Derecho Mercantil, n. ${ }^{\circ} 60$ (2018): 7-47: http://www.dlapipermb.com/images/docs/SIN-DOLO-Y-SIN-CULPA--MARTINEZ-Y-ROJAS.pdf.

Medina López, Diego. El derecho de los jueces. Bogotá: Legis, 2002.

Molla Descals, Alejandro, Gloria Berenguer Contri, Miguel Ángel Gómez Borja e Ismael Quintanilla Pardo. Comportamiento del Consumidor. Barcelona: Editorial UOC, 2006.

Pareja, Deicy. "El perfil transaccional: el reto del sector financiero". Riesgos Cero. 12 de diciembre de 2016: https://www.riesgoscero.com/blog/ el-perfil-transaccional-el-reto-del-sector-financiero.

RAE. "Definiciones de: hábito, costumbre, óbice, prudencia y diligencia". https://www.rae.es/. 
Real Decreto Legislativo 1/2007 del Reino de España. BOE n. ${ }^{\circ} 287$ del 30 de noviembre de 2007: https://www.boe.es/buscar/pdf/2007/BOE-A2007-20555-consolidado.pdf.

Salanié, Bernard. The Economics of Contracts. London: MIT, 2005.

Sánchez Belalcázar, Alfredo. "La calidad singular del consumidor financiero colombiano". En Temas de Protección al consumidor y regulación financiera. Círculo de Derecho Administrativo. Lima: Asociación Civil Revista de Derecho Administrativo CDA, 2018.

Sánchez-Juárez, Anna. "10 consejos de seguridad para usuarios digitales". Universitat Oberta de Catalunya. 4 de febrero de 2016: https://www. uoc.edu/portal/es/news/actualitat/2016/022-consejos-seguridad-in ternet.html.

Silva García, Fernando. "Régimen de responsabilidad de los administradores de instituciones financieras". Revista de Derecho Privado, n. 4 (1999): 70-86: https://revistas.uexternado.edu.co/index.php/derpri/ article/view/665.

Superintendencia de Industria y Comercio, Guía del Consumidor: http:// www.sic.gov.co/recursos_user/documentos/atencion_usuario/Guia_ Consumidor.pdf.

Superintendencia de Industria y Comercio. Definiciones de Información engañosa: https://www.sic.gov.co/informacion-enganosa.

Superintendencia de Sociedades. Oficio 220-015163 del 11 de febrero de 2013.

Superintendencia de Sociedades. Oficio 220-015163 del 11 de febrero de 2013: https://www.supersociedades.gov.co/nuestra_entidad/nor matividad/normatividad_conceptos_juridicos/32968.pdf.

Superintendencia de Sociedades. Proyecto de reforma al régimen societario, 2015.

Superintendencia Financiera de Colombia. Concepto 2010041709-000 del 10 de junio de 2010: https://www.superfinanciera.gov.co/jsp/16146.

Superintendencia Financiera de Colombia. Concepto 2013075203 del 25 de noviembre de 2013.

Superintendencia Financiera de Colombia. Concepto del 25 de noviembre de 2013: https://webcache.googleusercontent.com/search? q=cache:_eNfTYWu_W0J:https://www.superfinanciera.gov.co/descargas\%3Fcom\%3Dinstitucional\%26name\%3DpubFile1010856\%26down loadname\%3D2013075203.docx+\&cd=1\&hl=es\&ct=clnk\&gl=co\&clien$t=$ firefox-b-d. 
Superintendencia Financiera de Colombia. Concepto n. ${ }^{\circ}$ 2017107871-001 del 20 de octubre de 2017.

Superintendencia Financiera de Colombia. Información estadística anual SFC: https://www.superfinanciera.gov.co/inicio/11129.

Superintendencia Financiera de Colombia. "Reseña de jurisprudencia". https://www.superfinanciera.gov.co/inicio/10087981.

Superintendencia Financiera. Circular Externa 007 de 2018, 5 de junio: https://www.superfinanciera.gov.co/publicacion/10096745.

Superintendencia Financiera de Colombia. Delegatura para Funciones Jurisdiccionales, expediente 2017-034-137. Sentencia del 14 de marzo de 2018.

Superintendencia Financiera de Colombia. Delegatura para Funciones Jurisdiccionales, expediente 2015-0206. Auto del 21 de mayo de 2015.

Tomás Martínez, Gema. "La sustitución del «buen padre de familia» por el estándar de la «persona razonable»: reforma en Francia y valoración de su alcance". Revista de Derecho Civil 2, n. 1 (2015): 57-103: https:// www.nreg.es/ojs/index.php/RDC/article/download/109/89.

Tribunal de Justicia de la Comunidad Andina. Decisión del 24 de marzo de 1995, proceso n. ${ }^{\circ}$ 09-IP-94, solicitud de interpretación prejudicial formulada por el Consejo de Estado de la República de Colombia, Sala de lo Contencioso Administrativo, Sección Primera, respecto a los artículos 56, 58, literal f), y 84 de la Decisión 85 de la Comisión del Acuerdo de Cartagena. Interpretación de los artículos 69 y 73 de la Decisión 85; 88 y 103 de la Decisión 313 y artículos 99 y 114 de la Decisión 344. Diario Oficial del Acuerdo de Cartagena. Número 180. Año XI del 10 de mayo de 1995. Lima, Perú: http://webcache.googleusercontent.com/search?q=cache: m2AMd79IZFEJ:intranet.comunidadandina.org/Documentos/Procesos/ 9-ip-94.doc+\&cd=1\&hl=es\&ct=clnk\&gl=co\&client=firefox-b-d.

Tribunal Superior de Bogotá. Sala de Decisión Civil, expediente 110013 1990012015-206-01. Sentencia del 27 de octubre de 2016, MP: Germán Valenzuela Valbuena.

Tribunal Superior de Bogotá. Sala de Decisión Civil, expediente 11001 319900120175251 01. Sentencia del 24 de septiembre de 2019, MP: Julián Sosa Romero.

University of Oslo, "The principles of the European contract law", 2002: https://www.jus.uio.no/Im/eu.contract.principles.parts.1.to.3.2002/ 1.302.html. 
Ustáriz, Luis Humberto. Responsabilidad bancaria por fraude electrónico. Bogotá: Ibáñez, 2019.

Vieties, Álvaro Gómez. Enciclopedia de la Seguridad Informática. Madrid: Alfaomega Ra-Ma, 2007.

Wikipedia. La enciclopedia libre. "Definiciones de: perfil, portal (web), autenticación con contraseña de un solo uso, log transaccional y tecnología del engaño": https://es.wikipedia.org/.

"10 consejos para navegar seguro por internet". Info Spyware. https:// www.infospyware.com/articulos/10-consejos-para-navegar-seguropor-internet/.

"Cinco datos curiosos que no conocías". BBVA. 2 de agosto de 2018. https://www.bbva.com/es/deep-web-cinco-datos-curiosos-que-no-co nocias/.

"Conozca Hidemyass". HMA: https://www.hidemyass.com/es-es/about-us.

"Contrato único de vinculación persona jurídica de Itaú Corpbanca Colombia”. Itaú: https://www.itau.co/documents/10282/79571/Contra to\%20Unico\%20de\%20Vinculacioon\%2005062018.pdf.

"Deception technology, iniciando la ofensiva". IT Digital Security. 6 de febrero de 2018. https://www.itdigitalsecurity.es/reportajes/2018/02/ deception-technology-iniciando-la-ofensiva.

"Día de Internet: consejos para mejorar la seguridad al navegar". Revista Byte. 17 de mayo de 2019: https://revistabyte.es/ciberseguridad/ dia-de-internet-seguridad/.

"Frequently asqued questions". APPGATE: https://www.easysol.net/eng/. "Mal asegurados: No cubrirse frente al dólar está saliendo caro". Revista Dinero. 9 de enero de 2016: https://www.dinero.com/edicion-impresa/ pais/articulo/como-son-las-coberturas-para-riesgo-de-dolar/231432.

“Mejores VPN de 2019”. TOP1OVPN: https://www.top10vpn.com/mejo res-vpn/?bsid=c47se1 kw275\&gclid=EAlalQobChMI6vqVu8Ps5AIVB YeGCh346gcDEAAYASAAEgKrgfD_BwE.

"Perfil financiero y perfil". Central CRM: https://blog.central-crm.com/ 2019/04/perfil-financiero-y-perfil.html.

"Product of the Year de 2018, Summary report 2018". AV Comparatives. 25 de enero de 2019: https://www.av-comparatives.org/wp-content/ uploads/2019/02/avc_sum_201812_en.pdf.

"PSE: cómo funciona". PSE. www.pse.com.co/como-funciona. 
“¿Qué es un One Time Password?” Auronix. 2 de febrero de 2016: https: //www.auronix.mx/blog/2016/02/que-es-one-time-password.

"Reglamento general de términos y condiciones para productos, servicios y canales ofrecidos por BBVA Colombia a personas jurídicas". BBVA: https://www.bbva.com.co/content/dam/public-web/colombia/do cuments/home/footer/reglamentos/productos-personas-juridicas/ D02-Reglamento-Persona-Juridica.pdf.

"Reglamento Portal Empresarial Unificado". Davivienda: https://www. davivienda.com/wps/wcm/connect/empresas/7cc97c73-5ac7-48f79ab1-2c9168ecad6d/REGLAMENTO+PORTAL+EMPRESARIAL+UNIFI CADO+2018+.pdf?MOD=AJPERES\&CVID=miAnpYN.

"Reglamento banca por internet (personas naturales) de Bancolombia": https://www.grupobancolombia.com/wps/wcm/connect/1dcd5b4ba856-4cee-9df9-f497eb26f964/Reglamento+Banca+por+Internet.pdf? $M O D=A J P E R E S \& C V I D=I . B 62 R O$.

"Tu herramienta bancaria más segura: el sentido común". HMA. 14 de agosto de 2018: https://blog.hidemyass.com/es/safe-online-banking\# topic-5.

"What is a VPN and How Does it Work?" YouTube. 12 de diciembre de 2017: https://www.youtube.com/channel/UCEA9ROzwUTy6t-QdLuWrjnw. 